\title{
Radiative Effect and Mixing Processes of a Long-Lasting Dust Event over Athens, Greece, during the COVID-19 Period
}

\author{
Panagiotis Kokkalis ${ }^{1, *(\mathbb{D})}$, Ourania Soupiona ${ }^{2}$, Christina-Anna Papanikolaou ${ }^{2}{ }^{(}$, Romanos Foskinis ${ }^{2}$, \\ Maria Mylonaki ${ }^{2}$, Stavros Solomos ${ }^{3}$, Stergios Vratolis ${ }^{4}$ (D), Vasiliki Vasilatou ${ }^{4}$, Eleni Kralli ${ }^{2}$, Dimitra Anagnou ${ }^{2}$ (D) \\ and Alexandros Papayannis ${ }^{2}$ D \\ 1 Physics Department, Kuwait University, Safat 13060, Kuwait \\ 2 Laser Remote Sensing Unit, Department of Physics, National and Technical University of Athens, \\ 15780 Zografou, Greece; raniaphd@mail.ntua.gr (O.S.); papanikolaouca@mail.ntua.gr (C.-A.P.); \\ foskinis@mail.ntua.gr (R.F.); mylonakimari@mail.ntua.gr (M.M.); elkralli@survey.ntua.gr (E.K.); \\ dimiana@phys.uoa.gr (D.A.); apdlidar@mail.ntua.gr (A.P.) \\ 3 Research Centre for Atmospheric Physics and Climatology, Academy of Athens, 10680 Athens, Greece; \\ ssolomos@academyofathens.gr \\ 4 Environmental Radioactivity Laboratory (ERL), Institute of Nuclear \& Radiological Sciences \& Technology, \\ Energy \& Safety, National Centre of Scientific Research “Demokritos", 15310 Attiki, Greece; \\ vratolis@ipta.demokritos.gr (S.V.); vassiliki@ipta.demokritos.gr (V.V.) \\ * Correspondence: panagiotis.kokkalis@ku.edu.kw
}

\section{check for} updates

Citation: Kokkalis, P.; Soupiona, O.; Papanikolaou, C.-A.; Foskinis, R.; Mylonaki, M.; Solomos, S.; Vratolis, S.; Vasilatou, V.; Kralli, E.; Anagnou, D.; et al. Radiative Effect and Mixing Processes of a Long-Lasting Dust Event over Athens, Greece, during the COVID-19 Period. Atmosphere 2021, 12, 318. https://doi.org/ 10.3390/atmos12030318

Academic Editor: Xiaoguang Xu

Received: 22 December 2020

Accepted: 20 February 2021

Published: 28 February 2021

Publisher's Note: MDPI stays neutral with regard to jurisdictional claims in published maps and institutional affiliations.

Copyright: (c) 2021 by the authors. Licensee MDPI, Basel, Switzerland. This article is an open access article distributed under the terms and conditions of the Creative Commons Attribution (CC BY) license (https:/ / creativecommons.org/licenses/by/ $4.0 /)$.
Abstract: We report on a long-lasting (10 days) Saharan dust event affecting large sections of SouthEastern Europe by using a synergy of lidar, satellite, in-situ observations and model simulations over Athens, Greece. The dust measurements (11-20 May 2020), performed during the confinement period due to the COVID-19 pandemic, revealed interesting features of the aerosol dust properties in the absence of important air pollution sources over the European continent. During the event, moderate aerosol optical depth (AOD) values (0.3-0.4) were observed inside the dust layer by the ground-based lidar measurements (at $532 \mathrm{~nm}$ ). Vertical profiles of the lidar ratio and the particle linear depolarization ratio (at $355 \mathrm{~nm}$ ) showed mean layer values of the order of $47 \pm 9 \mathrm{sr}$ and $28 \pm 5 \%$, respectively, revealing the coarse non-spherical mode of the probed plume. The values reported here are very close to pure dust measurements performed during dedicated campaigns in the African continent. By utilizing Libradtran simulations for two scenarios (one for typical midlatitude atmospheric conditions and one having reduced atmospheric pollutants due to COVID19 restrictions, both affected by a free tropospheric dust layer), we revealed negligible differences in terms of radiative effect, of the order of $+2.6 \%\left(\mathrm{SW}_{\mathrm{BOA}}\right.$, cooling behavior $)$ and $+1.9 \%\left(\mathrm{LW}_{\mathrm{BOA}}\right.$, heating behavior). Moreover, the net heating rate (HR) at the bottom of the atmosphere (BOA) was equal to $+0.156 \mathrm{~K} / \mathrm{d}$ and equal to $+2.543 \mathrm{~K} / \mathrm{d}$ within $1-6 \mathrm{~km}$ due to the presence of the dust layer at that height. On the contrary, the reduction in atmospheric pollutants could lead to a negative $\mathrm{HR}(-0.036 \mathrm{~K} / \mathrm{d})$ at the bottom of the atmosphere (BOA) if dust aerosols were absent, while typical atmospheric conditions are estimated to have an almost zero net $\mathrm{HR}$ value $(+0.006 \mathrm{~K} / \mathrm{d})$. The NMMB-BSC forecast model provided the dust mass concentration over Athens, while the air mass advection from the African to the European continent was simulated by the Hybrid Single-Particle Lagrangian Integrated Trajectory (HYSPLIT) model.

Keywords: lidar; aerosols; dust event; COVID-19 lockdown; radiative forcing; Athens; Greece

\section{Introduction}

Dust aerosols have a large impact on climate, cloud formation, the precipitation cycle, aviation safety, and, finally, human health [1-9]. More specifically, their impact on climate concerns the direct and the indirect effects on the Earth's atmosphere radiation budget. The direct effect includes the scattering and absorbing role of these aerosols on the short- and 
long-wave radiation emitted by the sun and the Earth, respectively. According to the latest available report of the Intergovernmental Panel on Climate Change (see Figure 8.17 in [10]), the total direct radiative effect of mineral dust (coarse and fine modes) is estimated to be negative $\left(-0.1 \pm 0.2 \mathrm{~W} / \mathrm{m}^{2}\right)$, recently updated to $-0.11 \pm 0.3 \mathrm{~W} / \mathrm{m}^{2}$ [11], still with a high uncertainty. On the other hand, very large uncertainties still remain regarding the aerosols' (and mostly the dust particles') indirect radiative effect through aerosol-cloud interactions, which is equal to $-0.45 \pm 0.45 \mathrm{~W} / \mathrm{m}^{2}$ according to Figure 8.17 in [10]. The aerosol-cloud interaction involves the interactions of aerosol particles with liquid or ice clouds to change the cloud microphysical properties and suppress precipitation [12-14], thus modifying their lifetime and changing their ice content $[15,16]$. Furthermore, dust aerosols play a key role in the dynamics and thermodynamics of the atmosphere [14], but they may also cause severe health effects on humans [6-9], especially when combined with high air pollution levels. Furthermore, a recent study shows a link between air pollution and an increased risk of death from COVID-19 [17]. Therefore, it is of particular importance to study the spatiotemporal variability of particles' shape, concentration, size distribution, and refractive index, and other geometrical and physico-chemical properties [18-20], especially under specific conditions where local air pollution sources were minimized, as we will discuss in this section.

The main sources of dust particles in Southern Europe are the large arid areas of the Saharan desert, where more than 1-2 Tg of dust is lofted into the atmosphere on an annual rate $[11,21,22]$. In Southeastern Europe, Saharan dust intrusions frequently occur in the free troposphere from spring to autumn due to the high cyclonic activity over Northern Africa [23-29]. The majority of these events over the Mediterranean usually last from a few days up to one week during the autumn and summer periods [27,30-36]

In the past, several studies of the vertical variability of dust aerosol geometrical and physico-chemical properties have been performed in the European continent by the synergy of lidars, in situ instruments, sun photometers, satellite observations and model simulations, mainly in the frame of the European Aerosol Research Lidar Network (EARLINET) [20,32,37-44]. However, no such studies have been performed under specific conditions with very low local air pollution levels, such as those which prevailed during the COVID-19 confined period in Europe [45-48].

The first cases of COVID-19 were reported in China [49,50] in early winter 2019-2020, spreading over Europe and arriving in Greece in late February [51]. The lockdown period started in most European cities (including Athens) during March 2020 and lasted mainly up to June 2020 [46]. During this period, air traffic was nearly canceled and car traffic and other means of ground transportation, as well as industrial activities, were minimized on a European level; therefore, air pollution levels in most European cities showed very low concentrations (e.g., a reduction in $\mathrm{NO}_{2}$ by $32 \%$ in Athens; see also Figure A1, by $48 \%$ in Madrid and by $57-61 \%$ in Milan $[45,47,52-57])$. Similarly, an air pollution level reduction was also observed in many cities all over the world (Canada, Brazil, India, Cairo, Southeast Asia, etc.) [46,58-62]. Therefore, the importance of this study lies in the specific conditions which prevailed during the COVID-19 lockdown period in spring 2020, namely: (i) the very low levels of air pollution in Athens due to reduced emissions, (ii) the duration of the dust transport (more than 10 days), and (iii) the intensity of the dust event (high levels of layer aerosol optical depth (AOD) $>0.3-0.4$ at $535 \mathrm{~nm}$ ).

In this paper, we present in Section 2 the methodology and instrumentation used to follow this dust event under rare background conditions. The evolution of this warm air mass/dust advection across the Mediterranean and mainly over Athens will be further analyzed in terms of synoptic scale, in conjunction with systematic ground-based and space-borne measurements and model simulations (Section 3). Section 4 deals with the presentation of a case study, while Section 5 focuses on the radiative effect of the studied dusty air masses under the realistic scenario of reduced background pollution over our station. To our knowledge, this is the first time that the radiative effect is studied under the aforementioned unique conditions. Our conclusions are provided in Section 6. 


\section{Instrumentation and Simulation Tools/Models}

In order to analyze this strong event, we used a synergy of ground-based remote sensing (lidar) measurements, satellite data and complementary forecast/simulation and radiative transfer models. A short description of each tool used in this study is presented in next sub-sections.

\subsection{Lidar Systems at the National Technical University of Athens (NTUA)}

The campus of the National Technical University of Athens (NTUA) is located inside the Athens Basin $\left(37.96^{\circ} \mathrm{N}, 23.78^{\circ} \mathrm{E}\right.$, elevation $220 \mathrm{~m}$ asl. Figure 1). The advanced elastic-Raman lidar system aErosol and Ozone Lidar systEm (EOLE) of the Laser Remote Sensing Unit (LRSU) of NTUA [63] is based on a pulsed Nd:YAG laser system which emits, simultaneously, pulses at 354.93-532-1064.2 nm, with energies of 240-310-260 mJ, respectively, at $10 \mathrm{~Hz}$ repetition frequency. The laser beam containing all three wavelengths is expanded 3-times by an achromatic Galilean telescope before being emitted in the atmosphere. A Cassegrainian telescope of $300 \mathrm{~mm}$ diameter (focal length $600 \mathrm{~mm}$ ) collects all elastically backscattered lidar signals (354.93-532-1064.2 $\mathrm{nm}$ ), as well as those generated by the spontaneous vibrational-rotational Raman effect (by atmospheric $\mathrm{N}_{2}$ at 386.6 and $607.4 \mathrm{~nm}$, as well as by $\mathrm{H}_{2} \mathrm{O}$ at $407.5 \mathrm{~nm}$ ), within a field of view of 1.5 mrad. Thus, EOLE is able to provide independent and simultaneous measurements of the vertical profiles of the aerosol backscatter $\beta_{\text {aer }}$ (at 355, 532, and $1064 \mathrm{~nm}$ ) and extinction $\alpha_{\text {aer }}$ (at 355 and $532 \mathrm{~nm}$ ) coefficients, as well as the water vapor mixing ratio in the troposphere. Furthermore, EOLE provides the vertical profiles of the aerosol intensive parameters, namely the backscatterand extinction-related Ångström exponents $\left(\mathrm{AE}_{\alpha 355 / 532}, \mathrm{AE}_{\mathrm{b} 355 / 532}, \mathrm{AE}_{\mathrm{b} 532 / 1064}\right)$, as well as the lidar ratio (LR) at 355 and $532 \mathrm{~nm}$. The full overlap of EOLE is reached at $\sim 800 \mathrm{~m}$ asl.

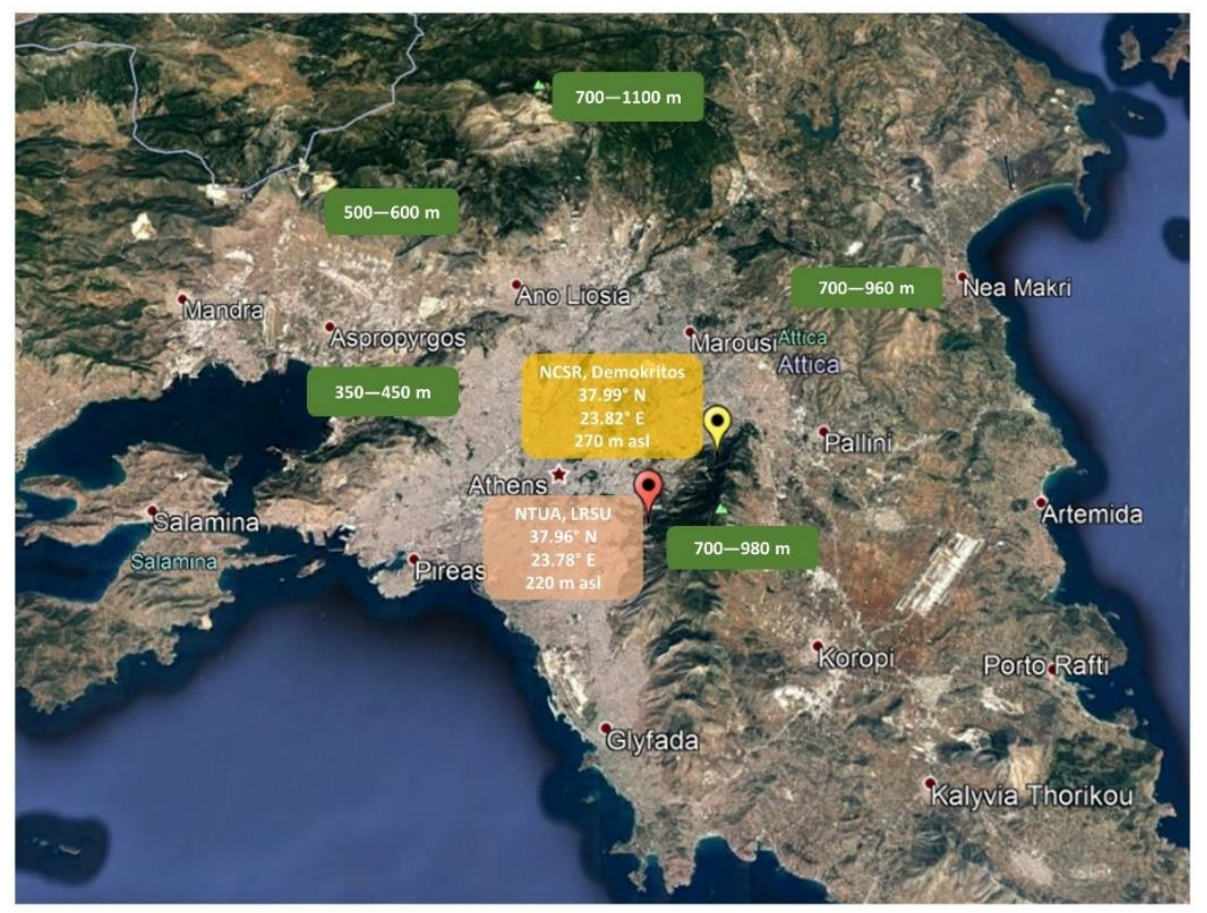

Figure 1. Map of the Greater Athens area (GAA) showing the locations of: The National Technical University of Athens (NTUA) lidar systems (37.96 N, 23.78 E, $220 \mathrm{~m}$ asl.; red pin), and the National Centre of Scientific Research (NCSR) facility $\left(37.99^{\circ} \mathrm{N}, 23.82^{\circ} \mathrm{E}, 270 \mathrm{~m}\right.$ asl.; yellow pin). The heights of the surrounding mountains are shown with green labels.

The NTUA DEPOLarization lidar systEm (DEPOLE) is based on the third harmonic frequency of a pulsed Nd:YAG laser emitting vertically a linearly polarized beam at $355 \mathrm{~nm}$ (polarization purity $>99.5 \%$ reached using a polarizing filter). It is equipped with a $200 \mathrm{~mm}$ 
diameter telescope (Dall-Kirkham Cassegrainian), with focal length $\mathrm{f}=1000 \mathrm{~mm}$, which collects the elastically backscattered lidar signals at $355 \mathrm{~nm}$ (at two polarization planes: parallel and perpendicular), which are optically separated by a polarizing beam splitter cube. The full overlap of DEPOLE is reached at $\sim 500 \mathrm{~m}$ asl. [63]. The average (systematic and statistical) uncertainty of the vertical profile of the particle depolarization ratio $\left(\delta_{\mathrm{p}}\right)$ is less than $15 \%$ [64-66].

By using the Raman technique, as proposed in $[46,47]$, the $\beta_{\text {aer }}$ and $\alpha_{\text {aer }}$ vertical profiles are retrieved with systematic uncertainties of $\sim 5-15 \%$ and $\sim 10-25 \%$, respectively $[67,68]$. Therefore, the corresponding uncertainty of the retrieved LR values is of the order of $11-30 \%$, while the uncertainty for $\mathrm{AE}_{\beta}$ and $\mathrm{AE}_{\alpha}$ ranges between $0.02-0.04$ and $0.03-0.08$, respectively, as estimated by propagation error calculations. Both lidars are designed according to the optical set-up of a typical EARLINET station [69], following all the EARLINET quality assurance tests and standards [64,70], while the primary aerosol products $\left(\alpha_{\text {aer }}\right.$ and $\left.\beta_{\text {aer }}\right)$ are retrieved by using the EARLINET Single Calculus Chain (SCC) $[65,66]$.

The process followed for the estimation of the optical properties from the lidar signal is summarized below: an aerosol-free reference height window has to be detected initially, where the normalized range-corrected lidar signal sufficiently fits the calculated attenuated molecular backscatter coefficient (Rayleigh-fit criterion) [64]. For this, the user provides the SCC input platform with an initial guess of that range (in our case, 6-12 km based on visual inspection of the range-corrected lidar signal), and the corresponding algorithm fine tunes this guess by applying different statistical tests to ensure that the shape of the measured signal corresponds to the shape of a Rayleigh signal [66]. Afterwards, the retrieval of the aerosol optical properties from the lidar signal starts from the identified reference height using the assumption of the lidar ratio value (Klett technique), or from the utilization of the Raman channel (Raman technique), for the case of daytime and nighttime retrievals, respectively.

\subsection{Optical Particle Counter at the National Centre of Scientific Research (NCSR) "Demokritos"}

The National Centre of Scientific Research (NCSR) "Demokritos" is situated about $7 \mathrm{~km}$ to the north from downtown Athens (Figure 1). It is representative of the atmospheric aerosol at suburban areas of the Athens Metropolitan area. At "Demokritos" station, among other instruments, an optical particle counter (OPC, Grimm 107@660 nm laser light wavelength) is in operation so as to acquire the particle size distribution in the size range of $250 \mathrm{~nm}$ to $10 \mu \mathrm{m}$ optical diameter. The OPC in an intercomparison at the WCCAP (World Calibration Centre for Aerosol Physics) exhibited a counting accuracy within $10 \%$ for the size range $250 \mathrm{~nm}$ to $1 \mu \mathrm{m}$ [71]. The instrument acquires a full-size distribution every $1 \mathrm{~min}$, while it uses a laser light at $660 \mathrm{~nm}$ wavelength. According to [72], during African dust outbreaks, the coarse aerosol mode $\left(\mathrm{PM}_{1}-\mathrm{PM}_{10}\right)$ increases by $43-46 \%$. We acquired $\mathrm{PM}_{1}$ and $\mathrm{PM}_{10}$ concentrations by using the OPC aerosol particle size distribution and an aerosol density of $1 \mathrm{~g} / \mathrm{cm}^{3}$. Based on the increase in the coarse aerosol mode, we examine the influence of Saharan dust at ground level.

\subsection{WRF-Chem Model}

We use the limited area of the WRF-Chem model [73,74] at $12 \times 12 \mathrm{~km}$ grid-space. Initial and boundary conditions are taken from the National Centers for Environmental Prediction (NCEP) operational Global Forecast System (GFS) model for the atmospheric parameters and from the NCEP operational SST for the sea surface temperature. The physical parameterizations of the model include the Mellor-Yamada-Janjic planetary boundary layer scheme [75], the Noah Land Surface Model for land properties [76], the Grell and Devenyi cloud convection scheme [73] and the Rapid Radiative Transfer Model for the short-wave and long-wave radiation. Dust emission is parameterized using the Air Force Weather Agency (AFWA) scheme [77] that includes five dust size bins with effective radii of $0.73,1.4,2.4,4.5$ and $8 \mu \mathrm{m}$, respectively. 


\subsection{MODIS Satellite Data}

The Moderate Resolution Imaging Spectroradiometer (MODIS) on-board the Terra and Aqua satellites is an operational satellite sensor which, among others, also performs observations of atmospheric aerosols. Particularly, MODIS has been providing Aerosol Optical Depth (AOD) retrievals at $500 \mathrm{~nm}$ since 2000, twice daily (under cloud-free conditions) on a near-global basis with high spatial resolution, and has acquired a well-respected status as one of the most reliable satellite datasets of AOD over ocean and land [78,79]. Besides AOD, there are several other aerosol properties that are retrieved by MODIS (e.g., Angström exponent, refractive index), which will not be used in the frame of this paper. Their retrieval is easiest over dark (in visible wavelengths) surfaces and, therefore, the first family of algorithms used by MODIS was the so-called "Dark Target" over land [80] and ocean $[81,82]$.

\subsection{DREAM Dust Model}

The NMMB/BSC-Dust model [83,84] provides online short to medium-range weather and dust forecasts from regional to global scales. It has been developed at the Barcelona Supercomputing Center-Centro Nacional de Supercomputación (BSC-CNS). At a global scale, NMMB/BSC is ranked among the best of AEROCOM dust models in terms of performance statistics for surface concentration, deposition and aerosol optical depth (AOD). At regional scale, the model reproduces significantly well the daily variability and seasonal spatial distribution of the dust optical depth over Northern Africa, the Middle East and Europe. It provides 24 vertical sigma-hybrid layers, having a $0.3^{\circ} \times 0.3^{\circ}$ horizontal resolution for each 72-h daily forecast. The meteorological fields are initialized every $24 \mathrm{~h}$ (at 12:00 UTC) with the NCEP global analysis $\left(0.5^{\circ} \times 0.5^{\circ}\right)$, and boundary conditions are updated every $6 \mathrm{~h}$ with the NCEP GFS.

\subsection{HYSPLIT Trajectory Model}

The Hybrid Single-Particle Lagrangian Integrated Trajectory model (HYSPLIT), developed by NOAA's Air Resources Laboratory (ARL) (https:/ / www.ready.noaa.gov (accessed on 22 December 2020) [85]), was used to study the atmospheric transportation of the dust particles during this extreme dust event. For the analysis of the backward air mass trajectories, we used the "normal" method, along with the GDAS1 (Global Data Analysis System) meteorological data. The vertical motion used to calculate the trajectories was the model vertical velocity. The initial values used to run the model were the coordinates of the NTUA lidar station and the altitude (asl.) of the dust aerosol layers observed. The duration of the backward air mass trajectories was set to $120 \mathrm{~h}$, which is a typical duration to characterize dust air masses in the Eastern Mediterranean [24,35]

\section{Observations-Experimental Results}

\subsection{Synoptic Meteorological Description of the 11-20 May 2020 Dust Event}

The weather conditions that favored this extreme dust event included a south-westerly jet at the lower tropospheric levels that was stream placed between a trough over Southwest Europe and a strengthening ridge over Southeastern Europe. The relative position of these two systems is evident in the upper tropospheric maps in Figure 2 from the WRF model at $12 \times 12 \mathrm{~km}$ grid space, on 14 May 2020 15:00 UTC. As seen in Figure 2a, the jet stream at $200 \mathrm{mb}$ is located at relatively southern latitudes $\left(25^{\circ} \mathrm{N}-33^{\circ} \mathrm{N}\right)$, with wind speeds exceeding $60 \mathrm{~m} / \mathrm{s}$ over Algeria. At $500 \mathrm{mb}$ height (Figure 2b), the center of the trough is located over the southwest parts of the Iberian Peninsula, while strong pressure gradients are evident over the arid areas of Algeria and Tunis. This combination of weather systems is responsible for the formation of the strong "Khamsin" winds that mobilize large amounts of Saharan dust in the area [86]. At the same time, the formation of a persisting high-pressure system over the eastern part of the Mediterranean (Figure 2b) resulted in the recirculation of the elevated dust layers over Greece and Turkey. 
(a)

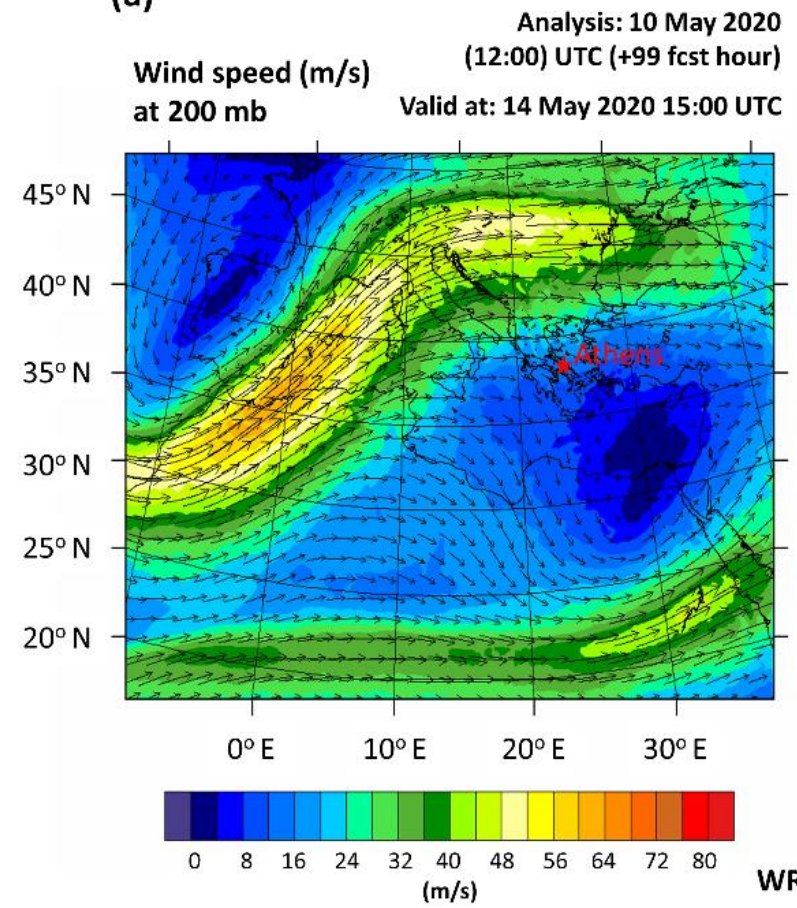

(b)

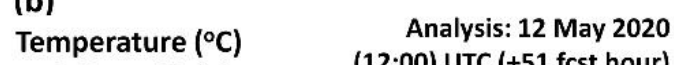
and Geop. Height at $500 \mathrm{mb}$

(12:00) UTC (+51 fcst hour)

Valid at: 14 May 2020 15:00 UTC

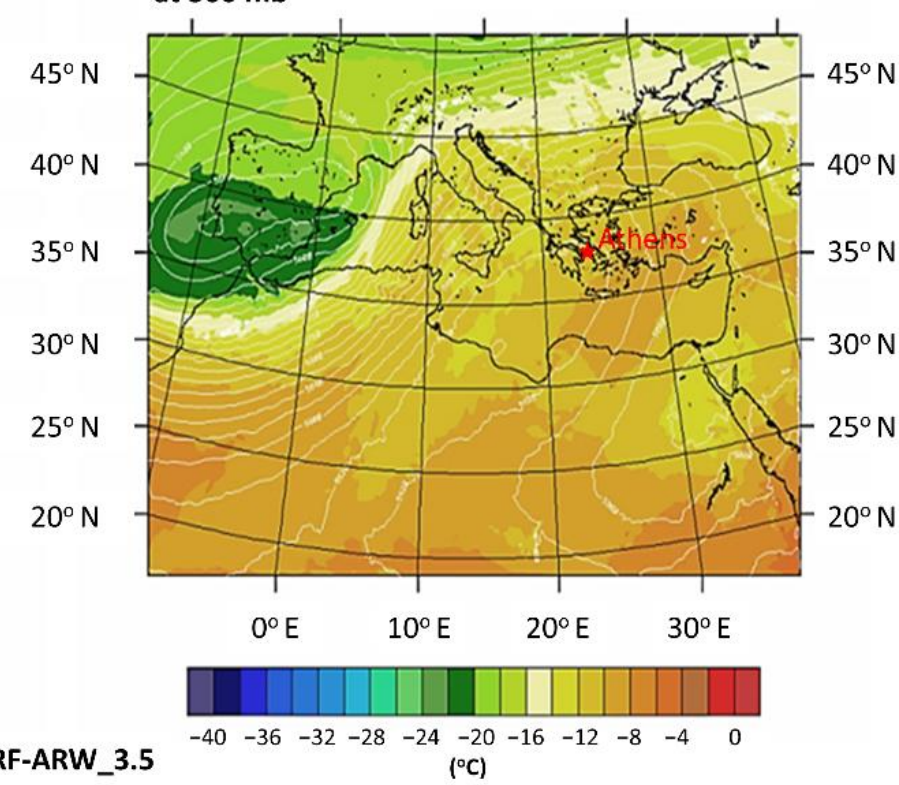

Figure 2. (a) Wind speed (in m/s) at $200 \mathrm{mb}$; (b) temperature (in ${ }^{\circ} \mathrm{C}$ ) and geopotential height at $500 \mathrm{mb}$, from WRF model.

The evolution of dust advection from the Sahara towards Greece is shown in Figure 3, as described by the WRF model for the period of interest. The formation of the dusty air mass is evident over Northeast Algeria and Tunisia on 12 May. The dust layers, which crossed the Mediterranean region on 13 and 14 May, were embedded into the anticyclonic cell that was centered over Greece from 14 to 18 May. This persisting high-pressure system resulted in the recirculation of the dusty air masses and in the consequent increase in atmospheric dust-loads over the Eastern Mediterranean until 21 May. On 22 May, the synoptic flow changed and the establishment of north winds over the Balkans resulted in ventilating the atmospheric dust towards southern latitudes. In the same figure, it is of interest to mention the high values of dust load which peaked on 15 May at 15:00 UTC $\left(2-2.5 \mathrm{mg} / \mathrm{m}^{2}\right)$.

Overall, two distinct transport paths of the air masses can be observed during the study period: (a) 10-15 May 2020 (phase 1), when fresh dust is transported from the Sahara towards SE Europe, and (b) 15-20 May 2020 (phase 2), when aged dust is trapped in a recirculating pattern over Greece. This is also supported later on (Section 3.2) by the HYSPLIT back-trajectories (Figure 4), but also from the retrieved aerosol optical properties (see also Figures 8 and 9). 

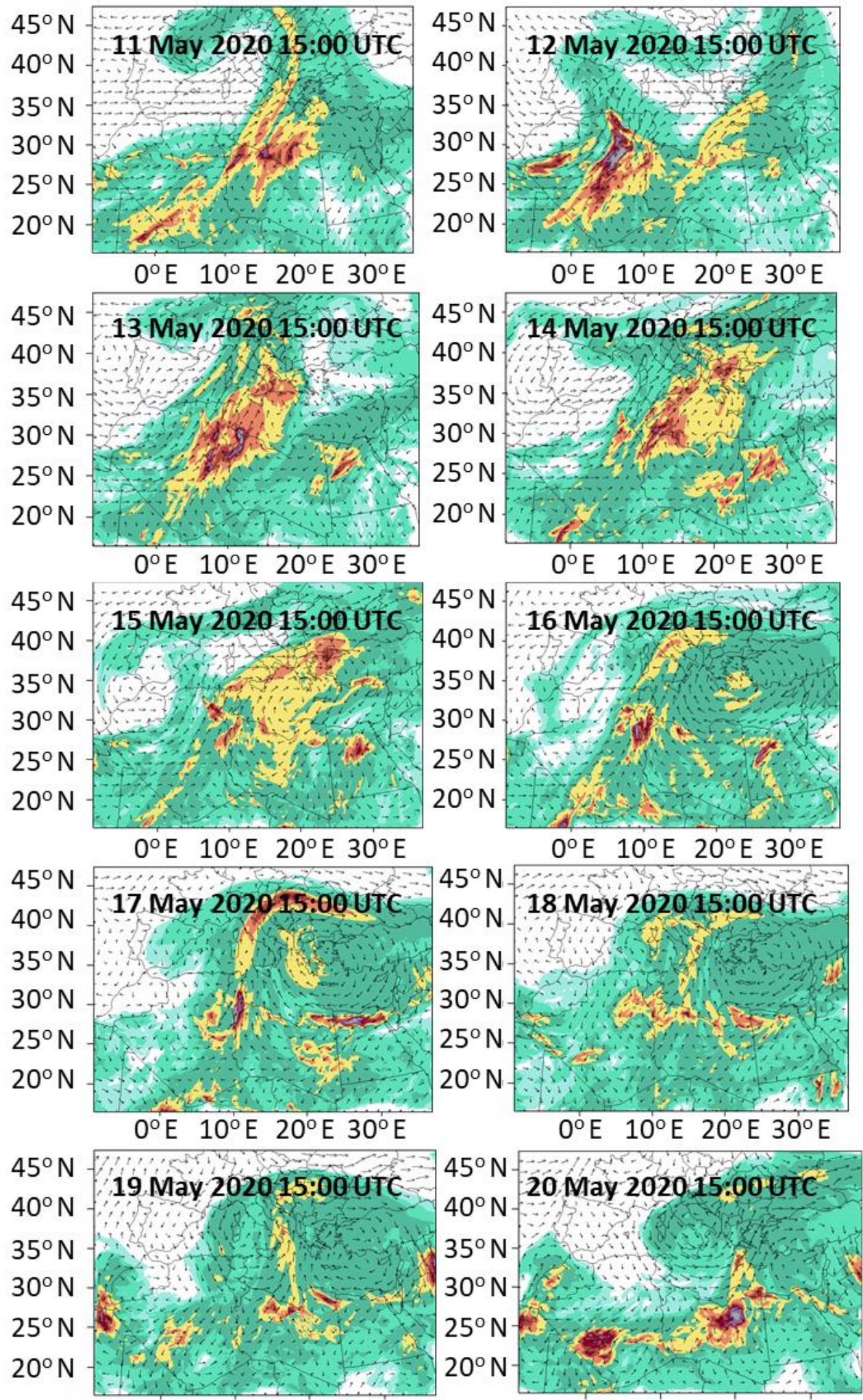

$$
\begin{gathered}
0^{\circ} \mathrm{E} \quad 10^{\circ} \mathrm{E} 20^{\circ} \mathrm{E} 30^{\circ} \mathrm{E} \\
\text { Dustload }\left(\mathrm{mg} / \mathrm{m}^{2}\right)
\end{gathered}
$$

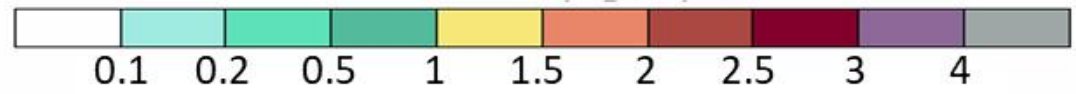

Figure 3. Vertically integrated dust load $\left(\mathrm{mg} / \mathrm{m}^{2}\right)$ and wind vectors at $2 \mathrm{~km}$ from WRF model (11-20 May 2020). 


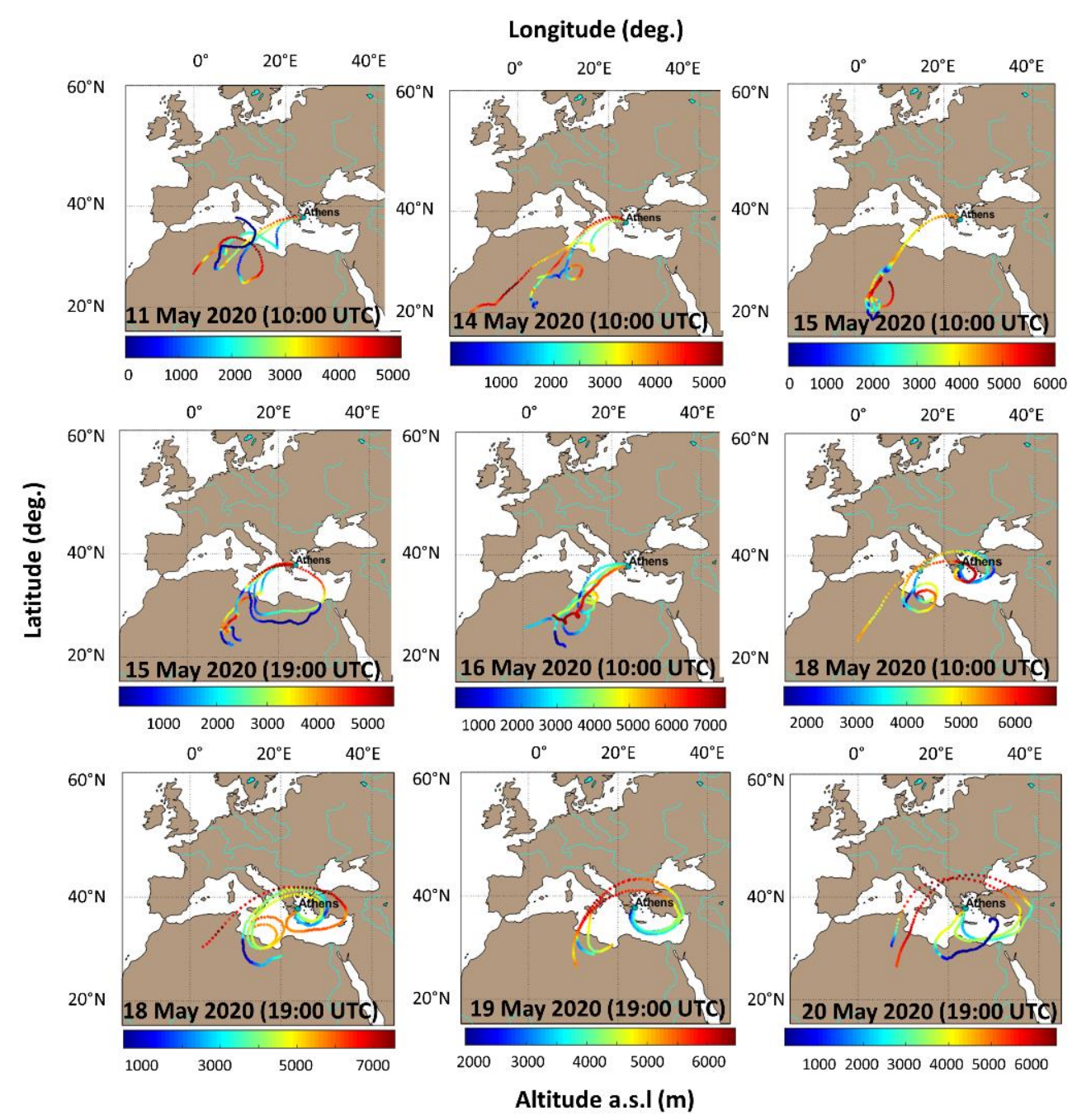

Figure 4. The 120-h backward trajectories for air masses arriving over Athens in the period 11-20 of May 2020.

\subsection{HYSPLIT Backward Trajectory Analysis}

The path travelled by the observed dust layers from Northern Africa to Athens was also verified using an air mass backward trajectory analysis based on the HYSPLIT simulation model (Figure 4). As can be seen in Figure 4 (first row), the air masses which arrived over Athens from 11 to 15 May at 10:00 UTC seemed to follow a similar pattern. They originated from North-Western Africa (Algeria, Mali, Mauritania), deep in the Saharan desert. After leaving the African continent, they followed an almost straight route towards Greece. Between 15 May (19:00 UTC) and 18 May (10:00 UTC), the air mass trajectories are slightly shifted to North-Eastern latitudes over Athens (Figure 4, second row), passing over Algeria, Tunisia and Libya. Later, from 18 May (19:00 UTC) to 20 May (19:00 UTC), the air mass trajectories starting from the North-Eastern Saharan region passed over Italy, the Balkans region and then over the industrial regions of Istanbul (Turkey), following an anticyclonic flow formed around a high-pressure system over Greece before their arrival over Athens (see also Figure 3). The increased residence time over Greece that is evident, for example, at 18, 19 and 20 May in Figure 4 results in more aged particles being detected by the lidar system over Athens.

\subsection{Dust Model Simulations}

The NMMB/BSC-Dust estimations of the vertical evolution of dust mass concentration $\left(\mu \mathrm{g} / \mathrm{m}^{3}\right)$ over Athens are presented in Figure 5. The dust mass concentration values at 2, 4 and $6 \mathrm{~km}$ height (approximately base, center and top, respectively) are depicted 
within a 6-h interval. According to the model, the massive export of dust load started on 10 May (00:00 UTC) and gradually ended on 22 May (18:00 UTC), with a total duration of $300 \mathrm{~h}$. During the first 6 days of the event, the maximum concentration values of the dust concentration peaked at $\sim 402 \mu \mathrm{g} / \mathrm{m}^{3}$ on 12 May (12:00 UTC) at a height of $4 \mathrm{~km}$. These values gradually became smaller during the following days, while the dust particles remained present between $2-4 \mathrm{~km}$ height asl. On the contrary, the dust concentration values at $2 \mathrm{~km}$ became larger on the 6th day of the event (18 May), shifting the center of mass of the estimated layers to lower heights. At $6 \mathrm{~km}$ height asl., the dust mass concentration remained below $100 \mu \mathrm{g} / \mathrm{m}^{3}$ throughout the event. Finally, the aerosol mass concentration at the aforementioned altitudes in the free troposphere tend to zero value on 22 May, at 18:00 UTC. Considering the models' performance, there is quite good agreement of the estimated geometrical properties (base, top, thickness) when compared to the ones observed by EOLE lidar, as we will see in Figure 8a.

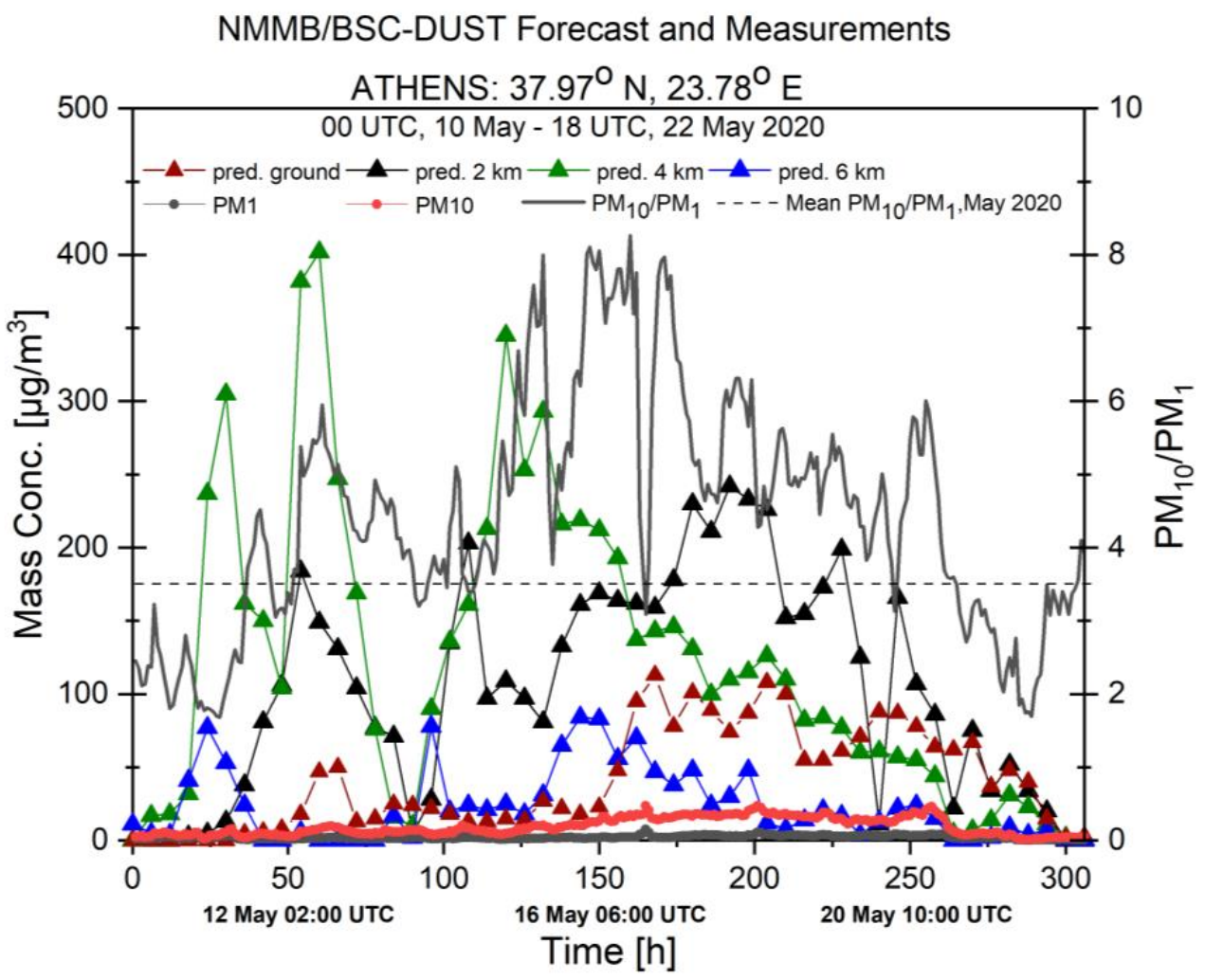

Figure 5. Dust mass concentration estimations by the NMMB/BSC-DUST model during the period 10-22 May 2020 and for the altitudes of 0, 2, 4, and $6 \mathrm{~km}$ (represented with red, black, green and blue triangles) over Athens, within a $6 \mathrm{~h}$ interval. $\mathrm{PM}_{10}$ (red circles) and $\mathrm{PM}_{1}$ (gray circles) hourly mass concentration measurements at the surface performed at NCSR Demokritos, along with the ratio $\mathrm{PM}_{10} / \mathrm{PM}_{1}$ (black solid line). The dashed black line corresponds to the mean May 2020 ratio $\mathrm{PM}_{10} / \mathrm{PM}_{1}$.

From the in-situ measurements performed at ground level at NCSR "Demokritos", we observe that while $\mathrm{PM}_{1}$ concentration (mainly representing local emissions) remains almost stable and at low levels, $\mathrm{PM}_{10}$ concentration increases rapidly on the 13 May, until 21 May.

As detected by the lidar, the dust layers remained detached during the study period. This is also reproduced in the model by the very low concentrations of dust at ground level compared to the free troposphere. The increase in $\mathrm{PM}_{10}$ concentrations, which is evident in ground measurements after 16 May, is probably related to downward turbulent mixing of dust particles inside the Planetary Boundary Layer (PBL). This increase is also depicted in the modeled surface concentrations of dust; however, it is overestimated 
by $50-80 \mu \mathrm{g} / \mathrm{m}^{3}$ (Figure 5). Such local scale processes inside the PBL cannot be easily reproduced at the mesoscale resolution of the model $\left(0.3^{\circ} \times 0.3^{\circ}\right)$, especially for regions of complex topography [87], thus explaining the discrepancy between modeled and measured values, especially at ground level.

\subsection{MODIS Satellite Data}

Figure 6 presents the MODIS "True Image" alongside the Combined Value-Added Aerosol Optical Depth normalized at $550 \mathrm{~nm}$ (AOD MODIS) product from both Terra and Aqua satellites per day of the long-lasting dust event (11-20 May). The cloud formation over Southern Europe is in accordance with wind vectors at $2 \mathrm{~km}$, as estimated by the WRF model (see Figure 3), especially for the period 14-20 May. The color scale layering represents the values of $A O D_{\text {MODIS }}$ at $500 \mathrm{~nm}$, in the scale of 0 (yellow) to 5 (dark red). As stated in Section 2.3, the efficiency of the MODIS AOD product maximizes under cloudfree conditions, thus, the AOD values are expected to be observed only in the absence of clouds. During the first 3 days of the event (11-13 May), the MODIS AOD MODIS values over Athens were around 0.1-0.3. The dust burden became more intense during the next

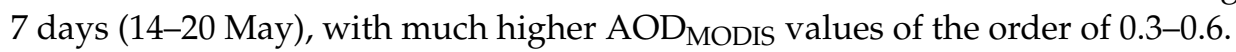

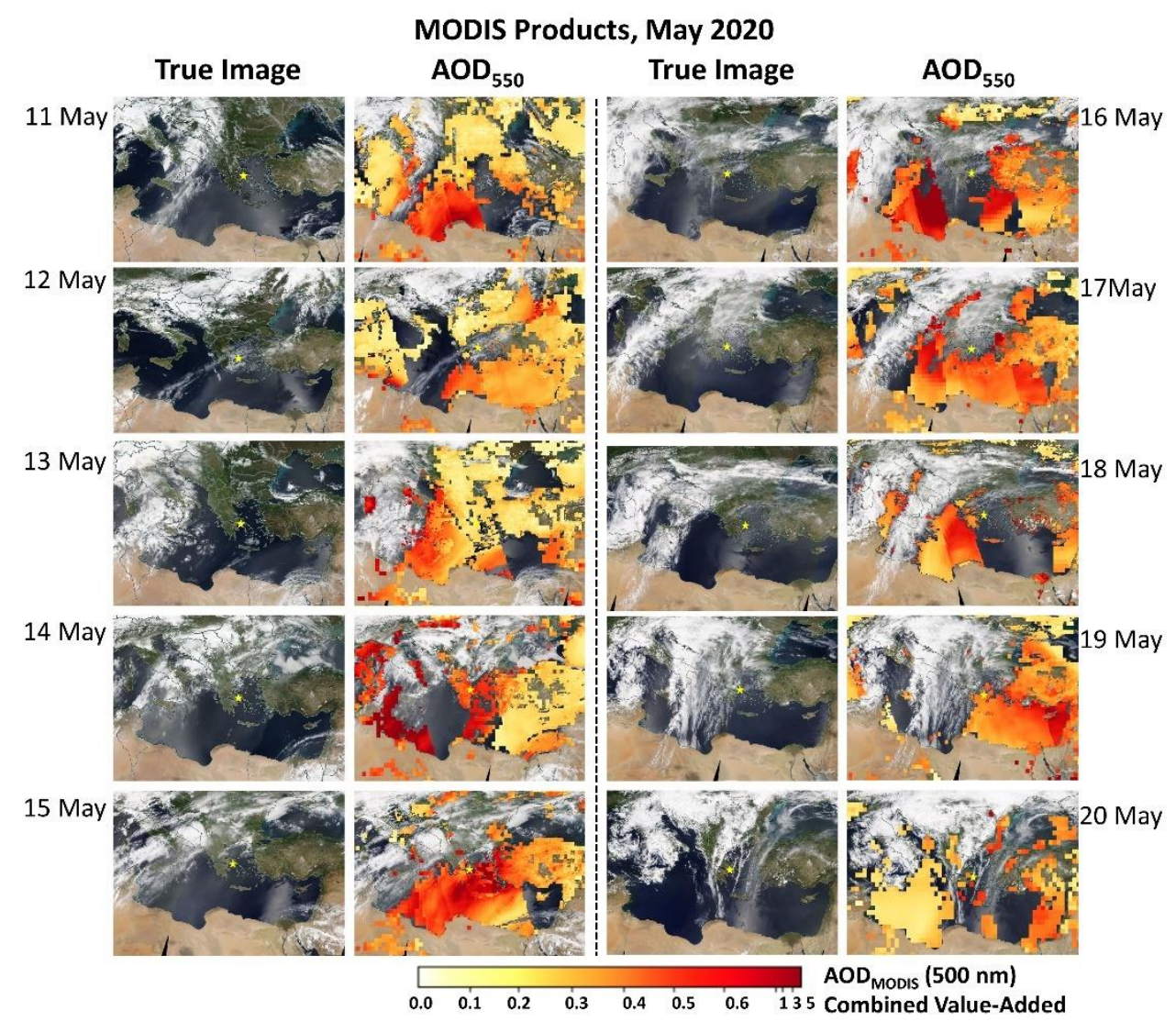

Figure 6. The "True Image" and the AOD MODIS products at $550 \mathrm{~nm}$ from both Terra and Aqua satellites per day during the period 11-20 May 2020.

\subsection{Ground-Based Aerosol Lidar Observations}

Ground-based lidar observations were used to illustrate the spatio-temporal evolution of the dust aerosol stratification during the measuring period ( $>50 \mathrm{~h}$ of measurements) (see Figure 7). According to the temporal evolution of the range-corrected lidar signals shown at $1064 \mathrm{~nm}$ (Figure 7a), an intense dust aerosol layer is observed between 2000 and $5000 \mathrm{~m}$ asl. during 11 May over Athens. On 13 May (see Figure 7b), during the daytime measurements (06:00-11:00 UTC), the dust layer is limited below $2 \mathrm{~km}$ height asl., while a thick aerosol layer appears during the nighttime lidar measurements (18:00-19:00 UTC) between 3000 
and 5000 asl. This layer, once split into two distinct layers (from ground to $3200 \mathrm{~m}$ and 4000-5000 m), persists in staying over Athens during 14 and 15 May (Figure 7c,d, respectively), while the lower layer is intensified during the daytime hours of 15 May (up to 16:48 UTC) over the daytime Planetary Boundary Layer (PBL), which is confined below $\sim 1200 \mathrm{~m}$ height (between 13:00 and 16:49 UTC). The latter atmospheric barrier has been estimated from the lidar signals by using the Extended Kalman Filtering technique and found to be within the typical monthly range (1300-1700 m), suppressed, however, $\sim 200 \mathrm{~m}$ here due to the presence of the free tropospheric dust load, as also reported by [88]. During the following day (16 May), the intense dust aerosol layer is well stratified in three distinct layers between the top of the PBL ( 1000 $\mathrm{m}$ height) and $3200 \mathrm{~m}$ height (Figure 7e). On the following days (18-20 May), the dust layer stays at constant levels (1000-4000 m) significantly attenuated over the Athenian PBL (denoted by black circles on Figure 7), showing a high aerosol burden over the city (Figure 7f-h). The days of 14-20 May coincide with the highest AOD values measured by MODIS (0.3-0.6). The free-tropospheric pure dust layer was also depicted by the space-borne lidar CALIPSO, over our station during May 2020 (Figure A2).

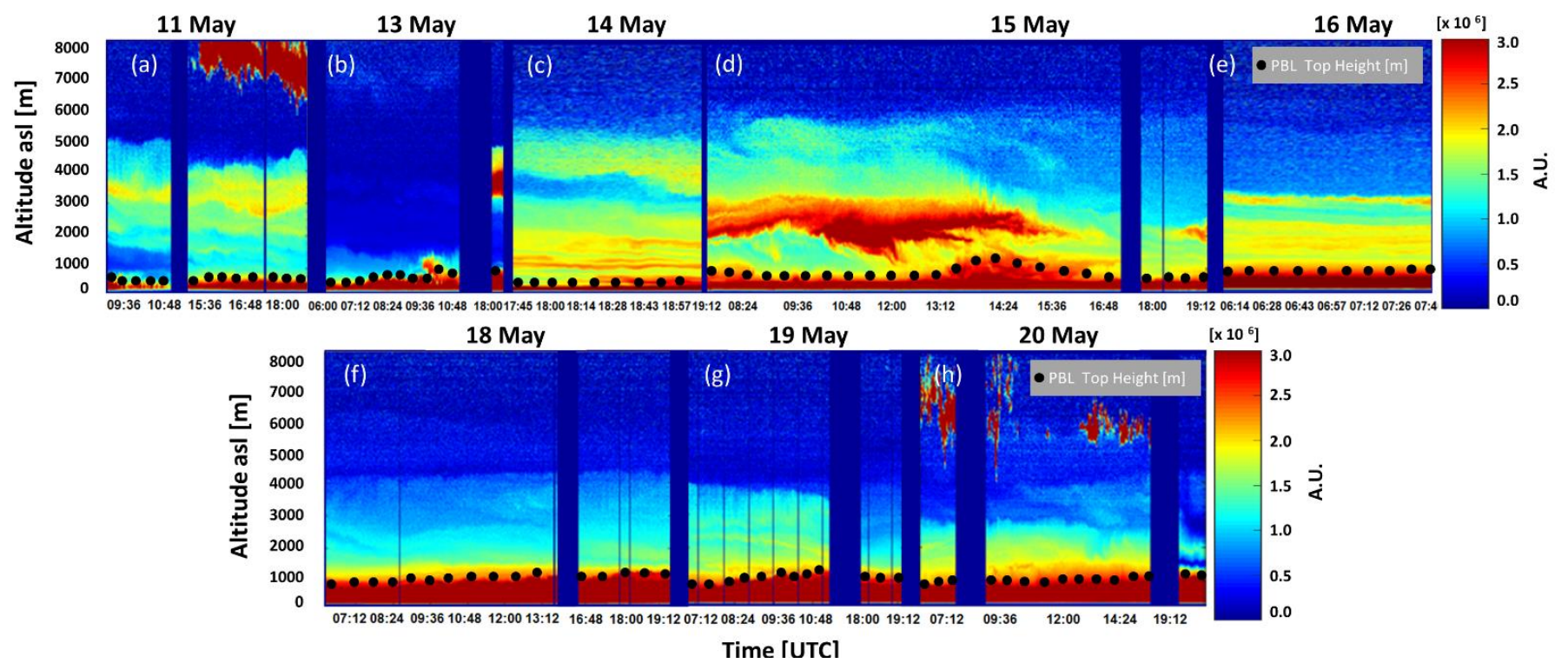

Figure 7. Spatio-temporal evolution of the range-corrected lidar signal at $1064 \mathrm{~nm}$, as observed by EOLE lidar over Athens from 11 May 2020 to 20 May 2020 (a-h). The boundary layer top height is denoted with black circles.

In the following Figures (Figure 8a-f), we present the geometrical and optical properties of the aerosol layers observed over Athens during this dust event, while in Table 1, the mean values for the whole studied period are presented, along with their standard deviation (SD), the range and the median value. Due to overlap effect, the base of dust aerosol layers is estimated for height levels above $1000 \mathrm{~m}$ during the whole period of the event, while the top reached, in some cases, $7000 \mathrm{~m}$ asl (Figure 8a). In the same graphic (Figure 8a), we also present the center of mass (COM) of each distinct dust layer according to [89], which in most cases coincides with the geometrical center of the dust layer. All values of the mean aerosol optical properties as well as their SD were calculated within the altitude ranges shown for each day in Figure 8a and for the $1 \mathrm{~h}$ measurement period under cloud-free conditions (daytime or nighttime). Consequently, seven daytime and five nighttime datasets were considered for further analysis (Figure $8 \mathrm{~b}-\mathrm{f}$ ). The $\alpha_{\mathrm{aer}}$ at both wavelengths (355 and $532 \mathrm{~nm}$, Figure 8b) were similar, with higher values $\left(\sim 164 \pm 39 \mathrm{Mm}^{-1}\right)$ on 13 May and a declining trend as the event evolved. A minimum is observed on the last day of measurements (20 May) of $\sim 25 \pm 10 \mathrm{Mm}^{-1}$ in both wavelengths. Identical values in the extinction profiles were also reported by [90] during the SALTRACE experiment in Barbados, as well as by [36] during the SHADOW field campaign in Senegal. 

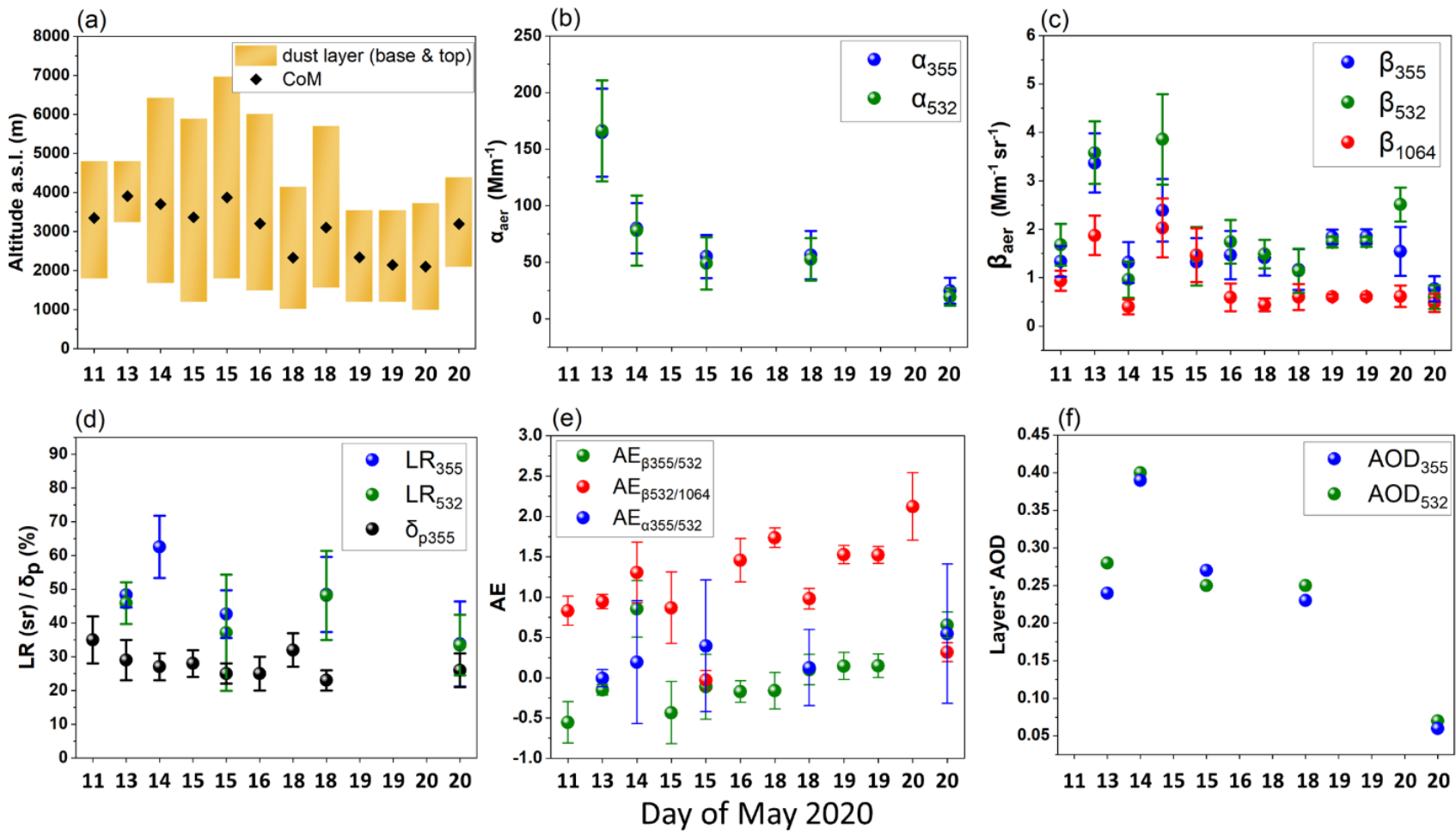

Figure 8. Geometrical (a) and mean optical properties (b-f) of each aerosol layer observed by the EOLE and DEPOLE lidar systems (during daytime and nighttime observations) over Athens during the dust event along with their SD.

Table 1. Mean geometrical and optical properties of the dust layers along with their SD during the two distinct phases of the long-lasting dust episode, as observed over Athens by the EOLE and DEPOLE lidar systems.

\begin{tabular}{ccc}
\hline Parameter & $\begin{array}{c}\text { 1st Phase } \\
\text { (11 May-15 May Noon) }\end{array}$ & $\begin{array}{c}\text { 2nd Phase } \\
\text { (15 May Night-20 May) }\end{array}$ \\
\hline Base $(\mathrm{m})$ & $1982 \pm 879$ & $1424 \pm 390$ \\
Top (m) & $5476 \pm 811$ & $4749 \pm 1300$ \\
CoM (m) & $3579 \pm 273$ & $2786 \pm 645$ \\
$\alpha_{355}\left(\mathrm{Mm}^{-1}\right)$ & $122 \pm 60$ & $45 \pm 18$ \\
$\alpha_{532}\left(\mathrm{Mm}^{-1}\right)$ & $122 \pm 62$ & $40 \pm 18$ \\
$\beta_{355}\left(\mathrm{Mm}^{-1} \mathrm{sr}^{-1}\right)$ & $2.1 \pm 1.0$ & $1.4 \pm 0.4$ \\
$\beta_{532}\left(\mathrm{Mm}^{-1} \mathrm{sr}^{-1}\right)$ & $2.5 \pm 1.4$ & $1.5 \pm 0.5$ \\
$\beta_{1064}\left(\mathrm{Mm}^{-1} \mathrm{sr}^{-1}\right)$ & $1.3 \pm 0.8$ & $0.7 \pm 0.3$ \\
$\delta_{\text {p355 }}(\%)$ & $30 \pm 4$ & $26 \pm 3$ \\
$\mathrm{LR}_{355}(\mathrm{sr})$ & $55 \pm 10$ & $42 \pm 7$ \\
$\mathrm{LR}_{532}(\mathrm{sr})$ & $46 \pm 6$ & $40 \pm 8$ \\
$\mathrm{AE}_{\beta 355 / 532}$ & $-0.07 \pm 0.64$ & $-0.09 \pm 0.57$ \\
$\mathrm{AE}_{\beta 532 / 1064}$ & $0.99 \pm 0.22$ & $1.20 \pm 0.73$ \\
$\mathrm{AE}_{\alpha 355 / 532}$ & $0.09 \pm 0.14$ & $0.36 \pm 0.21$ \\
$\mathrm{AOD}_{532}$ & $0.34 \pm 0.08$ & $0.19 \pm 0.10$ \\
$\mathrm{AOD}_{355}$ & $0.32 \pm 0.11$ & $0.19 \pm 0.11$ \\
\hline
\end{tabular}

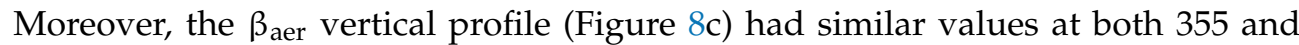
$532 \mathrm{~nm}$ during the whole event, and even in some days of measurements $(11,13,15$ and 20 May) the mean $\beta_{532}$ became larger than the mean $\beta_{355}$. Such an excess in $\beta_{532}$ values was also reported by $[36,91]$ (SHADOW). It should also be noted that the SD of the two optical parameters, $\alpha_{\text {aer }}$ and $\beta_{\text {aer }}$, decreases as the event evolves, indicating that the probed dusty layers become more stable and uniform with the aging of the dust event. 
Concerning the intensive optical properties, the $\mathrm{LR}_{355}$ inside the layers was equal to the $\mathrm{LR}_{532}$ for the whole period (Figure 8d), or even exceeded it in some cases (see also Figure 10f), giving an indication of non-mixed layers of Saharan dust aerosols [91]. Consequently, the ratio of the lidar ratios $\left(\mathrm{LR}_{355} / \mathrm{LR}_{532}\right)$ was found around 1 for all the measurements, indicating the absence of spectral dependence for the case of pure dust [37,92]. A descending trend was found for $\delta \mathrm{p}_{355}$, which took its highest value on the first day of the event (11 May, $\delta_{\mathrm{p} 355}=35 \pm 7 \%$ ) and the lowest one on the evening of 18 May $\left(\delta_{\mathrm{p} 355}=23 \pm 3 \%\right)$. It should be reminded here that $\delta_{\mathrm{p}}$ values greater than $30 \%$ are representative for pure dust [36,91,93-95]. The $\mathrm{AE}_{\beta 355 / 532}, \mathrm{AE}_{\beta 532 / 1064}$ and $\mathrm{AE}_{\alpha 355 / 532}$ had an increasing trend during the event (Figure 8e), ranging from -1.33 to 0.85 , from -0.03 to 2.12 and from -0.01 to 0.50 , respectively, taking mean values of $-0.08 \pm 0.26,1.13 \pm 0.21$ and $0.25 \pm 0.60$, respectively, (Table 1 ) in accordance with data provided in $[31-34,38,39,44]$. On the contrary, the AOD at both wavelengths, inside the dust layer, showed a decreasing trend during the event (Figure 8f), ranging from 0.39 (14 May) to 0.06 (20 May) and from 0.40 (14 May) to 0.07 (20 May) at 355 and $532 \mathrm{~nm}$, respectively. This gradual decrease (increase) with time for $\delta_{\mathrm{p} 355}, \mathrm{AOD}\left(\mathrm{AE}_{\alpha}\right.$, and $\left.\mathrm{AE}_{\beta}\right)$ is of specific interest in terms of aging and mixing processes, and is associated with the change in the atmospheric circulation and the path travelled explained previously (see Figure 4) in an atmospheric environment mostly free from local (continental) aerosol emissions due to the COVID-19 restrictions. This gradual decrease (increase) in $\delta_{\mathrm{p} 355}, \mathrm{AOD}\left(\mathrm{AE}_{\alpha}\right.$, and $\left.\mathrm{AE}_{\beta}\right)$, as the event evolves with time, is supported by the fact that the air mass trajectories initially followed a straight route from North Africa to Athens during the first phase of the event (11-15 May 10:00 UTC), while during the second phase of the event (15 May at 19:00 UTC-20 May at 19:00 UTC, as already discussed in Figure 4) they passed over the industrial regions of Istanbul (Turkey), where the dust aerosols were probably enriched with small anthropogenic particles, giving rise to the $A E_{\alpha}$ and $A E_{\beta}$ values and decreasing the values of $\delta_{p 355}$. By further analyzing the aerosol optical retrievals, we identified differences between the two phases of the event.

The differences in the geometrical and optical properties between these two phases are well depicted in Table 1. Firstly, lower geometrical properties (base, top, COM) are reported for the 2 nd phase compared to the 1st one, indicating that gravitational forces designated the dust stratification, since the residence time of the particles in the atmosphere extended due to circulation. This extra circulation also affected the dust load (dry deposition of the coarser particles), as depicted by the mean values of $\alpha_{\text {aer }}$ and $\beta_{\text {aer }}$ and AOD, which reduced to around half $\left(\alpha_{355}=45 \pm 18 \mathrm{Mm}^{-1}, \alpha_{532}=40 \pm 18 \mathrm{Mm}^{-1}\right.$, $\beta_{355}=1.4 \pm 0.4 \mathrm{Mm}^{-1} \mathrm{sr}^{-1}, \beta_{532}=1.5 \pm 0.5 \mathrm{Mm}^{-1} \mathrm{sr}^{-1}, \beta_{1064}=0.7 \pm 0.3 \mathrm{Mm}^{-1}$ $\left.\mathrm{sr}^{-1}\right)$ the corresponding values observed during the 1st phase $\left(\alpha_{355}=122 \pm 60 \mathrm{Mm}^{-1}\right.$, $\alpha_{532}=122 \pm 62 \mathrm{Mm}^{-1}, \beta_{355}=2.1 \pm 1.0 \mathrm{Mm}^{-1} \mathrm{sr}^{-1}, \beta_{532}=2.5 \pm 1.4 \mathrm{Mm}^{-1} \mathrm{sr}^{-1}, \beta_{1064}=1.3$ $\left.\pm 0.8 \mathrm{Mm}^{-1} \mathrm{sr}^{-1}\right)$. The mean values of $\delta \mathrm{p}_{355}$ and LR also decreased, depicting that the air mass circulation played a crucial role in the aging of the dust particles from almost pure [36,91,93-96] to long-range transported [20,33,37,39,90,97,98]. Finer particles reached over Athens after 15 May, as shown by the increase in the mean $\mathrm{AE}_{\alpha 355 / 532}$ and $\mathrm{AE}_{\beta 532 / 1064}$ values.

The aforementioned observation regarding the two distinct transportation phases of the dust plume is further supported by the comparison of the $\mathrm{LR}_{355}$ values, obtained during the two phases of the event and reported here, with the corresponding literature values regarding pure and polluted dust (Figure 9). During the first time period (contains 11 and 14 May), the mean LR $_{355}$ obtained by our ground-based measurements is very close to pure dust observations reported by dedicated campaigns in the African region (SAMUM and SHADOW), but also long-range transported pure dust over Barbados (SALTRACE). On the other hand, during the second time period (contains measurements performed on 15 (night), 18 and 20 May), our LR $_{355}$ values are in the cluster of mixed and polluted dust, similar to values also reported by other studies. 


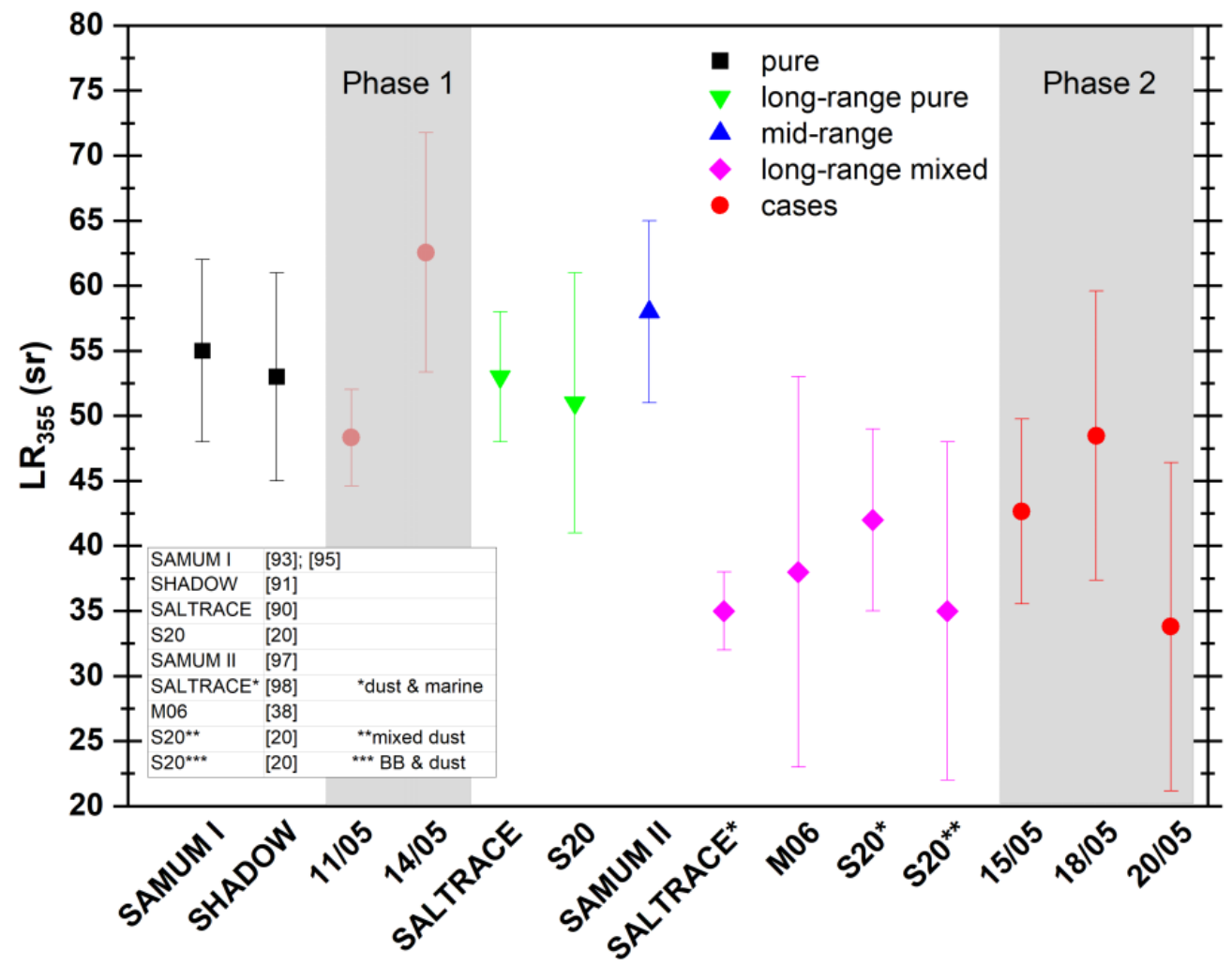

Figure 9. $\mathrm{LR}_{355}$ values reported by various campaigns that correspond to pure (either directly from the source or long-range transportation) and mixed/polluted dust, along with the values reported in this study (red circles inside a grey frame)] [20,38,90,91,93,95,97,98]

\section{Case Study Analysis}

In the following paragraphs, we will present two selected case studies during the 10-day period, focusing on the vertical distribution of the dust aerosol extensive and intensive optical properties. The selection of these days was based on the different paths followed by the air masses starting from the Saharan region and arriving over Athens. On 15 May, the air masses arrived directly to Athens; on 18 May, the air masses, embedded in the anticyclonic flow as described in Section 3.2, were mixed with anthropogenic ones passing over the Balkans and the industrial area of Istanbul.

\subsection{Case I: 15 May 2020}

The vertical profile of $\beta_{\text {aer }}$ (Figure 10a) at all the wavelengths for the case study of 15 May (15:50-16:50 UTC) reveals a thick aerosol layer between 2000 and $6500 \mathrm{~m}$. Moreover, the $\beta_{\text {aer }}$ shows almost equal values at all wavelengths inside the dust aerosol layer. Concerning the vertical profiles of $\mathrm{AE}_{\beta 355 / 532}$ and $\mathrm{AE}_{\beta 532 / 1064}$ on the same day (Figure 10b), they show small values inside the aerosol layer (-1.33-0.3), indicating the presence of coarse aerosols. The high values of $\delta_{p}$ at $355 \mathrm{~nm}(0.2-0.3)$ corroborate the depolarizing ability of the probed dust aerosols (Figure 10c).

Concerning the nighttime measurements of 15 May (18:46-19:46 UTC, Figure 10, bottom), the $\beta_{\text {aer }}$ at $532 \mathrm{~nm}$ has slightly larger values compared to the $\beta_{\text {aer }}$ at $355 \mathrm{~nm}$. According to the vertical distributions of $\beta_{\text {aer }}$ and $\delta_{p}$, the aerosol layer remained quasi stable between 2500 and $6000 \mathrm{~m}$ height asl., showing mean values of $\mathrm{LR}_{355}: 43 \pm 7 \mathrm{sr}, \mathrm{LR}_{532}$ : $37 \pm 17$ sr and $\delta_{\mathrm{p}}: 25 \pm 3 \%$. 

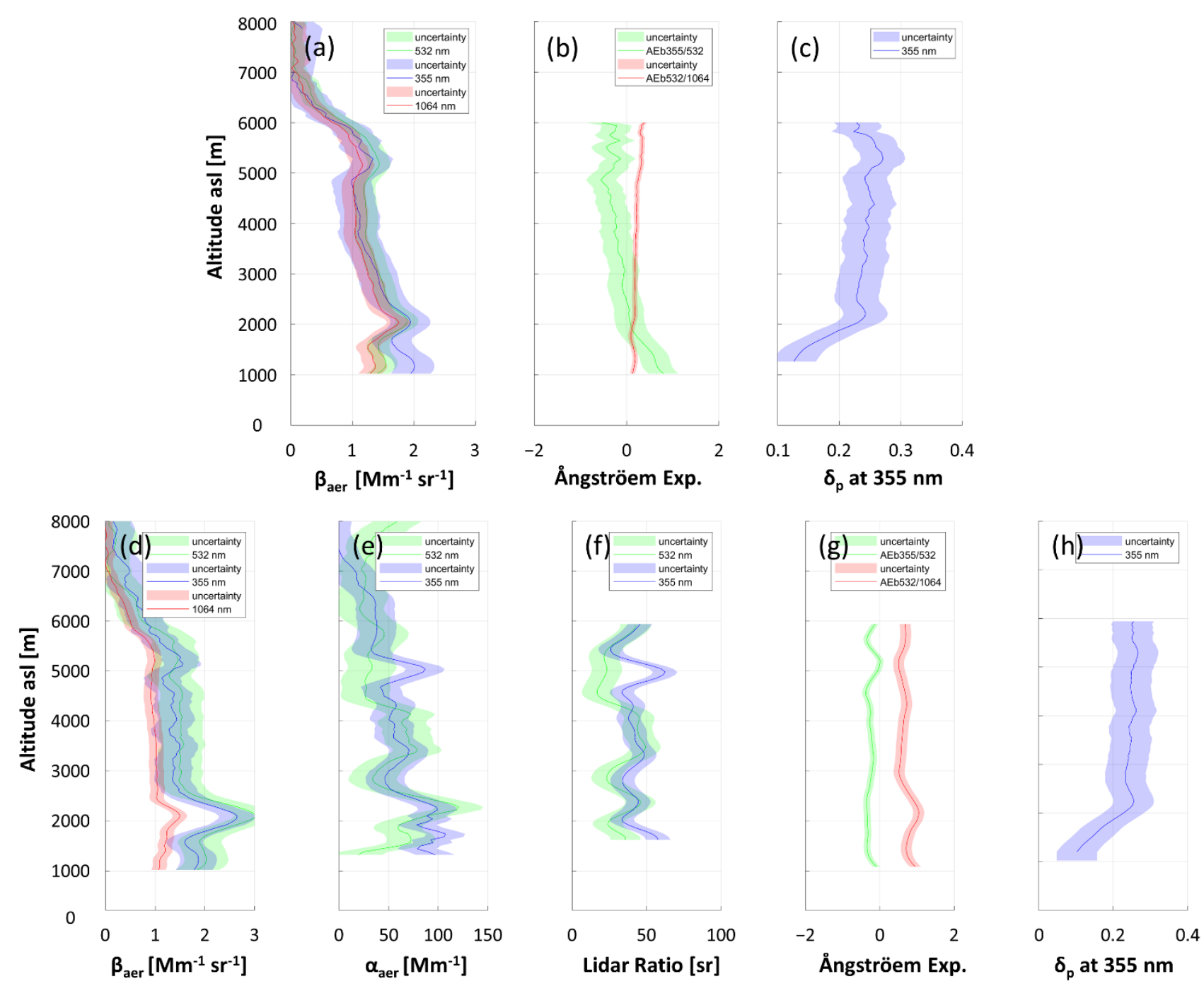

Figure 10. Vertical distribution of optical properties (a-h) of the aerosol layers observed over Athens on 15 May 2020 (top) daytime (15:50-16:50 UTC), (bottom) nighttime (18:46-19:46 UTC).

\subsection{Case II: 18 May 2020}

The dust event on 18 May also shows significant intensity, as seen on the vertical profiles of $\beta_{\text {aer }}$. Again, the $\beta_{\text {aer }}$ at $355 \mathrm{~nm}$ and $532 \mathrm{~nm}$ wavelengths presents similar values (Figure 11).

The $\mathrm{AE}_{\beta 355 / 532}$ is equal to 0 during both the daytime and nighttime lidar measurements, indicating large particles $[34,35,45]$ On the other hand, the $\mathrm{AE}_{\beta 532 / 1064}$ seems to show slightly higher values $(>1)$ during the daytime lidar measurements compared to the ones observed during the nighttime $\left(\mathrm{AE}_{\beta 532 / 1064} \sim\right)$. Additionally, the $\mathrm{LR}_{355}$ and $\mathrm{LR}_{532}$ present equal mean values, $48 \pm 11 \mathrm{sr}$ and $48 \pm 13 \mathrm{sr}$, respectively, during the nighttime, indicating wavelength independence of dust particles, as discussed by [36]. The $\delta_{\mathrm{p} 355}$ presents higher values during the daytime measurements ( $32 \pm 5 \%$ ) compared to the ones present during nighttime measurements $(23 \pm 3 \%)$, in accordance with the change in the synoptic pattern on this day and in terms of air mass backward trajectories. We have to mention here that the two presented case studies concern the optical properties of dust aerosols which arrived over Athens without significant mixing with locally emitted air masses, due to the COVID-19 local transportation restrictions leading to reduced aerosol emissions. Therefore, we could argue that the measured optical properties of the probed aerosols are representative of dust aerosols mixed with inter-regional continental aerosols, rather than local ones over the height of $1-1.5 \mathrm{~km}$ asl. 

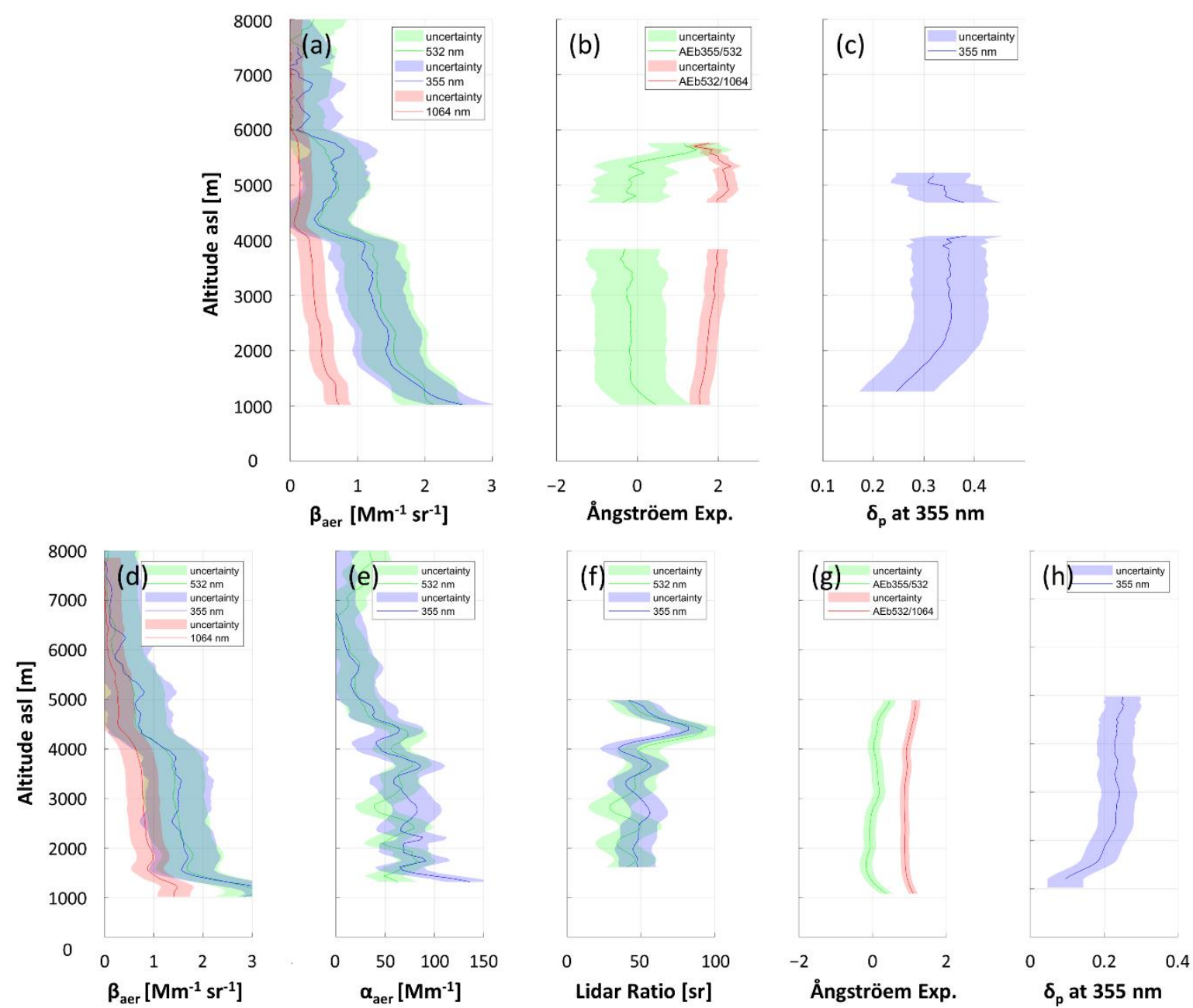

Figure 11. Vertical distribution of optical properties (a-h) of the aerosol layers observed over Athens on 18 May 2020 (top) daytime (09:30-10:30 UTC), (bottom) nighttime (18:30-19:30 UTC).

\section{Radiative Effect Calculations Using LibRadtran}

In order to estimate the radiative effect (RE) of the dust event over Athens, we firstly calculated the dust mass concentration profiles from our lidar measurements by following the procedure introduced by [97] for the calculation of the dust-related backscatter coefficient and [37] for the estimation of the height-resolved mass concentration of the dust-related backscatter coefficient. The mass profiles were then used as an input in the LibRadtran radiative transfer model version 2.0.2. [99]. The uvspec program that calculates the radiation field in the Earth's atmosphere was implemented for the disort radiative transfer equation (1-D geometry), and the downwelling and upwelling shortwave (SW, $0.28-2.5 \mu \mathrm{m}$ ) and longwave (LW, 2.5-40 $\mu \mathrm{m}$ ) irradiances at the top of the atmosphere (TOA, $120 \mathrm{~km}$ ) and bottom of the atmosphere (BOA, ground level) were simulated. It should be noticed here that SW and LW ranges are treated separately by LibRadtran, and all the cases correspond to cloud-free conditions. The OPAC library 4.0 [100] was used for desert spheroids (T-matrix calculations) in the mineral accumulation mode (MIAM) with $\mathrm{R}_{\text {MIAM }} \in[0.005,20]$ in $\mu \mathrm{m}$. The library uses an outdated dust refractive index spectrum in IR, which may substantially bias the LW radiative flux calculations. The RE depicts the perturbation in flux in the atmosphere caused by the presence of the aerosol layers in relation to that calculated under clear-sky conditions, and can be expressed as $[13,101]$ : $R E(z)_{N E T}=\Delta F^{\text {loaded }}-\Delta F^{\text {reference }}$, where the net flux, $\Delta F$, at a level $z$ is the difference between the downwelling and upwelling flux. In addition to the RE calculations, the radiative effect of the loaded atmosphere was also assessed from the vertical profile of the 
rate of heating of the atmosphere by the absorption of radiation called radiative heating rate $(\mathrm{HR})$, which, accordingly to the RE, is calculated as: $\triangle H R(z)_{N E T}=H R_{N E T}^{\text {loaded }}-H R_{N E T}^{\text {reference }}$.

Simulations were performed at 10:00 UTC on 18 May 2020, since at this time of measurement the solar zenith angle is small $\left(18.78^{\circ}\right)$, providing high solar irradiances proper to clearly depict the atmospheric situation. We initiated our simulations by assuming a Hypothetical scenario in order to estimate how the presented dust layer, in the free troposphere, can affect such a typical atmosphere (midlatitude summertime atmospheric conditions [102]). Afterwards, we proceeded with a more Realistic scenario, which depicts the current situation. Specifically, in the Realistic scenario, the local pollutants are reduced within the PBL due to the quarantine $\left(-30 \% \mathrm{NO}_{2},-2 \% \mathrm{CO}_{2}\right.$ [52]), the free troposphere is loaded with Saharan dust particles and, additionally, we took into account an extreme low ozone event where the total column ozone dropped down to 280-295 DU [103]. Table 2 summarizes the estimations of the instantaneous dust RE both at the BOA and TOA, as well as of the net heating rate within the atmosphere of both scenarios (Hypothetic and Realistic). In the Realistic scenario, the net RE is higher in absolute value at the BOA and almost equal at the TOA, compared to the Hypothetical one. The heating rate within the atmosphere, from 1000 to $6000 \mathrm{~m}$, where the dust layer was observed, has a positive sign in both scenarios and is slightly lower in the Realistic scenario, which depicts the contribution of the reduced concentrations of the pollutants.

Table 2. Instantaneous radiative effect (RE) calculations estimated by LibRadtran during 10:00 UTC on 18 May 2020 for the two scenarios (Hypothetical, Realistic).

\begin{tabular}{ccc}
\hline & 18 May 2020, 10:00 UTC & \\
\hline Radiative Effect (RE) & Hypothetical Scenario & Realistic Scenario \\
\hline $\mathrm{SW}$ BOA $\left(\mathrm{W} / \mathrm{m}^{2}\right)$ & -155.2 & -159.3 \\
$\mathrm{LW}$ BOA $\left(\mathrm{W} / \mathrm{m}^{2}\right)$ & 16.9 & 17.2 \\
$\mathrm{Net}_{\text {BOA }}\left(\mathrm{W} / \mathrm{m}^{2}\right)$ & -138.3 & -142.1 \\
$\mathrm{SW}$ TOA $\left(\mathrm{W} \mathrm{m}^{2}\right)$ & -20.5 & -20.9 \\
$\mathrm{LW}$ TOA $\left(\mathrm{W} / \mathrm{m}^{2}\right)$ & 12.3 & 12.8 \\
Net TOA $\left(\mathrm{W} / \mathrm{m}^{2}\right)$ & -8.2 & -8.1 \\
Atm. Heat. rate $(\mathrm{K} / \mathrm{d})$ & 2.6 & 2.5 \\
{$[1-6 \mathrm{~km}]$} & & \\
\hline
\end{tabular}

In order to further explore the RE in our case (see also Figure A3), we plotted the net HR of (i) the typical atmosphere $\left(H R_{N E T}^{\text {typical }}\right)$, (ii) the reference atmosphere $\left(H R_{N E T}^{\text {reference }}\right)$ and (iii) the dust loaded with reduced pollutants atmosphere $\left(H R_{N E T}^{\text {loaded }}\right)$ and their differences:

$$
\begin{aligned}
& \triangle H R(z)_{i-i i i}=H R_{N E T}^{\text {typical }}-H R_{\text {NET }}^{\text {reference }}(\text { Figure 12a) and } \\
& \Delta H R(z)_{i i-i}=H R_{N E T}^{\text {typical }}-H R_{\text {NET }}^{\text {reference }} \text { (Figure 12b). }
\end{aligned}
$$

In this way, the $\triangle H R(z)_{i-i i i}$ depicts the absorption of radiation within the atmospheric column due to the reduced pollutant concentrations, while the $\Delta H R(z)_{i i-i}$ depicts the corresponding absorption of radiation within the atmospheric column due to the additional dust load.

The net HR of specific altitude ranges is presented in Figure 12a. At the BOA, the reduced concentrations of the pollutants result in a negative net $\mathrm{HR}$ equal to $-0.036 \mathrm{~K} / \mathrm{d}$ due to the reduced molecular absorption in the SW range, while in a typical atmosphere this value would be opposite in sign and equal to $+0.006 \mathrm{~K} / \mathrm{d}$. Additionally, the dust loaded atmosphere with the reduced pollutants has a positive net HR equal to $0.156 \mathrm{~K} / \mathrm{d}$. Within the dust layer $(1-6 \mathrm{~km})$, the net HR of the reference atmosphere is reduced by $50 \%$ compared to the one of a typical atmosphere $(+0.004 \mathrm{~K} / \mathrm{d}$ and $+0.008 \mathrm{~K} / \mathrm{d}$, respectively). On the contrary, the net heating rate of the loaded atmosphere is much higher, reaching the value of $+2.470 \mathrm{~K} / \mathrm{d}$, due to the high AOD within this range. At the TOA, the highest net $\mathrm{HR}$ is estimated for a typical atmosphere $(+2.740 \mathrm{~K} / \mathrm{d})$ since the reduction in the pollutants and ozone is estimated to have a decrease of around $9 \%(2.490 \mathrm{~K} / \mathrm{d})$ compared to the 
aforementioned typical atmospheric conditions. Even a lower net HR equal to $2.420 \mathrm{~K} / \mathrm{d}$ is estimated at the same altitude for the dust loaded atmosphere (further decrease of $3 \%$ ).

(a)

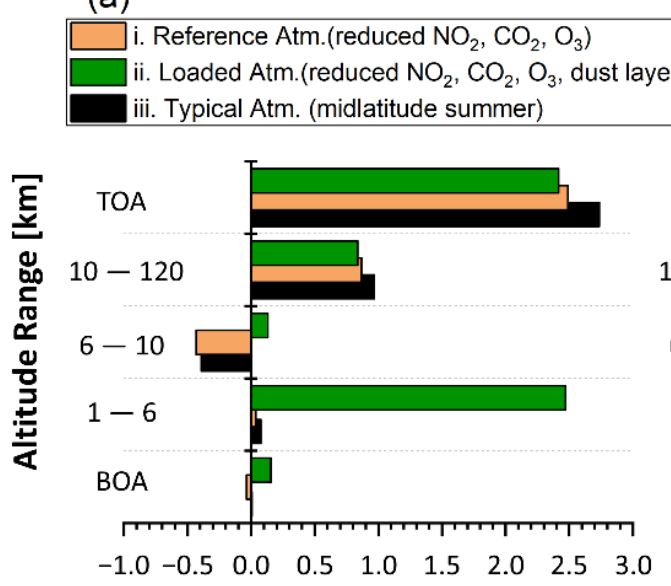

Net heat. rate $(\mathrm{SW}+\mathrm{LW})[\mathrm{K} / \mathrm{d}]$ (b)

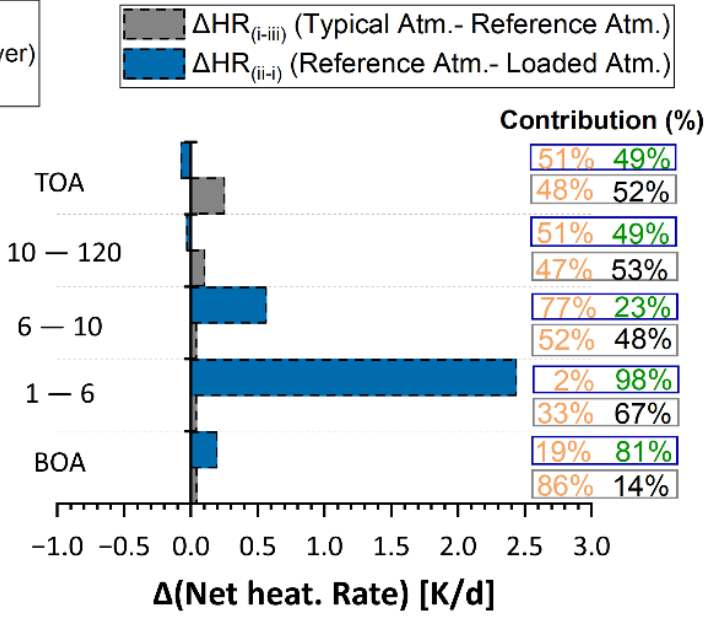

Figure 12. (a) Profiles of the net radiative heating rate (HR) of: (i) a typical atmosphere (black bars), (ii) the reference atmosphere (orange bars), (iii) the dust loaded with reduced pollutants atmosphere (green bars); (b) the net HR difference $(\triangle H R$ ) between: (i) the typical and reference atmospheres (blue bars), and (ii) the reference and the loaded atmosphere (gray bars). The information is given for specific altitude ranges: BOA, 1-6 km (dust layer), 6-10 km (upper troposphere), 10-20 km (upper atmosphere) and TOA. The percentages next to the corresponding bars depict the contribution of each of the two atmospheric conditions to the corresponding $\Delta H R$ values.

In Figure 12b, the difference between the typical and the reference atmosphere gives a positive $\Delta \mathrm{HR}$, which reaches the value of $+0.042 \mathrm{~K} / \mathrm{d}$ at the $\mathrm{BOA}$, and this value is designated by $86 \%$ due to the reduction in pollutants within the boundary layer. However, the presence of the dust layer does not leave the net HR at the BOA unaffected, since despite the reduced pollutants, the $\Delta \mathrm{HR}$ reaches the value of $+0.192 \mathrm{~K} / \mathrm{d}$ (scattering and absorption of the dust particles). Within the dust layer (1-6 km), $98 \%$ of the positive $\Delta H R$ (equal to $+2.433 \mathrm{~K} / \mathrm{d}$ ) is attributed to the dust loaded atmosphere, where the presence of dust aerosol led again to an increase in the scattering (increase in the upward and downward diffuse irradiance) and absorption of, mainly, the SW radiation. In the absence of the dust layer, the $\Delta \mathrm{HR}$ would be equal to $+0.04 \mathrm{~K} / \mathrm{d}$ due to the heating that an atmosphere with reduced pollutants would have created based on a typical atmosphere. In the range of 6-10 km, the reference atmosphere is the major contributor ( $52 \%$ and $77 \%$, respectively) of each $\Delta \mathrm{HR}$ $\left(\Delta \mathrm{HR}_{\mathrm{i}-\mathrm{iii}}, \Delta \mathrm{HR}_{\mathrm{ii}-\mathrm{i}}\right)$, which reach the positive values of +0.04 and $+0.563 \mathrm{~K} / \mathrm{d}$, respectively. Here, the net heating rate is lower compared to the previous altitude range $(1-6 \mathrm{~km})$ due to the significantly lower AOD (absence of dust particles). At the TOA, the $\triangle \mathrm{HR}$ between the loaded and the reference atmosphere is negative in sign but close to zero $(-0.072 \mathrm{~K} / \mathrm{d})$. On the contrary, the $\Delta \mathrm{HR}$ between the reference and the typical atmosphere is positive in sign and equal to $+0.248 \mathrm{~K} / \mathrm{d}$. Taking into account that the absorption of the Saharan dust particles is more pronounced at the ultraviolet (UV) spectrum, it could be concluded that its presence partially balances the effect of reduced levels of ozone on the upper atmosphere. Otherwise, a higher percentage of the UV radiation would have reached the ground.

\section{Conclusions}

In the period 10-20 May 2020, the meteorological conditions prevailing over the eastern Mediterranean enabled the formation of a moderate (in terms of aerosol load) long-lasting Saharan dust event over Greece. The event was followed by a synergy of ground-based and space-borne remote sensing, as well as in situ instrumentation. The measurements were performed during the COVID-19 lockdown period over Greece, which 
was accompanied by a general restriction of transport activities over Europe. As a consequence, during this period the levels of air pollution, especially over the megacity Athens, were significantly reduced, as in the entire European continent.

High AOD values (even up to 0.6) were observed by both MODIS (at $550 \mathrm{~nm}$ ) and ground-based lidar measurements (at 355 and $532 \mathrm{~nm}$ ). Moreover, high $\delta_{\mathrm{p} 355}$ values ranging from 23 to $35 \%$ were measured inside the dust aerosol layers, which were usually observed between 1000 and $6500 \mathrm{~m}$ asl. The variations in the values of $\delta_{\mathrm{p} 355}$, as well as in those of LR (from 34 to $63 \mathrm{sr}$ at $355 \mathrm{~nm}$ ) and $\mathrm{AE}$ (from - 1.33 to 0.85 for the $\mathrm{AE}_{\beta 355 / 532}$ ), can be attributed to aging and mixing processes due to the different paths travelled during the long-range transport of at least $120 \mathrm{~h}$, as estimated by HYSPLIT model (before and after 16 May). Moreover, instantaneous radiative effect calculations at BOA and TOA were estimated by LibRadtran for two scenarios. One using typical atmospheric profiles (Hypothetical), and one using reduced atmospheric pollutants (Realistic) due to the COVID-19 restrictions, revealed negligible differences in terms of radiative effect, of the order of $+2.6 \%\left(\mathrm{SW}_{\mathrm{BOA}}\right.$, cooling behavior) and $+1.8 \%$ ( $\mathrm{LW}_{\mathrm{BOA}}$, heating behavior). Within the dust layer $(1-6 \mathrm{~km})$, almost $98 \%$ of the positive heating rate is attributed to the dust load. At the TOA, the reduction in the pollutants and ozone is estimated to have a decrease in the net HR of around $9 \%$, while an additional decrease of $3 \%$ is estimated due to the presence of dust in the free troposphere, compared to the typical atmospheric conditions.

Overall, the 10-day dust event presented in this work provides valuable information by revealing the aerosol optical properties of strongly depolarizing Saharan dust particles and their impact on the climate's radiative balance and atmospheric dynamics. Moreover, the aerosol dust measurements, performed during the confined period of the COVID-19 pandemic over Athens aloft, revealed interesting features of the aerosol dust properties, based on the $\delta_{\mathrm{p} 355}, \mathrm{LR}_{355}, \mathrm{LR}_{532}, \mathrm{AE}_{\beta 355 / 532} \mathrm{AE}_{\beta 532 / 1064}$ and $\mathrm{AE}_{\mathrm{a} 355 / 532}$ values, in the absence of important air pollution sources over the European continent. Furthermore, we observed significant differences between the aerosol optical properties observed before and after 15 May, when the dust circulation pattern changed from the direct advection from Africa to Greece (before 15 May) to the anticyclonic flow which prevailed after 15 May over Greece (when the dusty air masses passed over the Balkans and the industrial regions of Istanbul, Turkey). At ground level, a significantly higher $\mathrm{PM}_{10}$ to $\mathrm{PM}_{1}$ ratio was observed in the period extending from the 13 to 21 of May. This is an indication of the strong mixing of Saharan dust and local aerosol in the vertical.

Author Contributions: Supervised and designed the research, A.P. and P.K.; performed the measurements, M.M., O.S., R.F. and E.K.; analyzed and visualized the data, M.M., C.-A.P., O.S., D.A.; performed WRF-Chem model simulations, S.S.; performed LibRadtran simulations, O.S. and R.F.; analyzed the PM data at ground level, S.V. and V.V.; discussed the results and wrote the manuscript, all authors. All authors have read and agreed to the published version of the manuscript. Authorship must be limited to those who have contributed substantially to the work reported.

Funding: This research was founded jointly by the PANhellenic infrastructure for Atmospheric Composition and climatE change (PANACEA) research project (MIS 5021516), implemented under the Action Reinforcement of the Research and Innovation Infrastructure, and the Operational Program Competitiveness, Entrepreneurship, and Innovation (NSRF 2014-2020), co-financed by Greece and the European Union (European Regional Development Fund).

Institutional Review Board Statement: Not applicable.

Informed Consent Statement: Not applicable.

Data Availability Statement: The data used in this study are available upon request from the corresponding author.

Acknowledgments: Maria Mylonaki's work was supported by the Hellenic Foundation for Research and Innovation (HFRI) under the HFRI Ph.D. Fellowship (Grant no. 669). Alexandros Papayannis, Romanos Foskinis, Eleni Kralli, Dimitra Anagnou and Christina-Anna Papanikolaou gratefully acknowledge support by the PANhellenic infrastructure for Atmospheric Composition and climatE 
change (PANACEA) research project (MIS 5021516), implemented under the Action Reinforcement of the Research and Innovation Infrastructure, and the Operational Program Competitiveness, Entrepreneurship, and Innovation (NSRF 2014-2020), co-financed by Greece and the European Union (European Regional Development Fund). All authors acknowledge the Barcelona Super ComputingDust REgional Atmospheric Model 8b model (BSC-DREAM8b; https://ess.bsc.es (accessed on 22 December 2020)), the National Oceanic and Atmospheric Administration (NOAA) Air Resources Laboratory (ARL) for the provision of the Hybrid Single-Particle Lagrangian Integrated Trajectory (HYSPLIT; https: / /www.ready.noaa.gov/index.php (accessed on 22 December 2020)) model, and Google Earth for providing the map shown in Figure 1. The European Aerosol Research LIdar NEtwork (EARLINET) lidar data were made available through the financial support by the Aerosols, Clouds and Trace gases Research InfraStructure (ACTRIS) European Research Infrastructure project funded by the European Union's Horizon 2020 Research and Innovation program (grant agreement no. 654169).

Conflicts of Interest: The authors declare no conflict of interest.

\section{Appendix A}

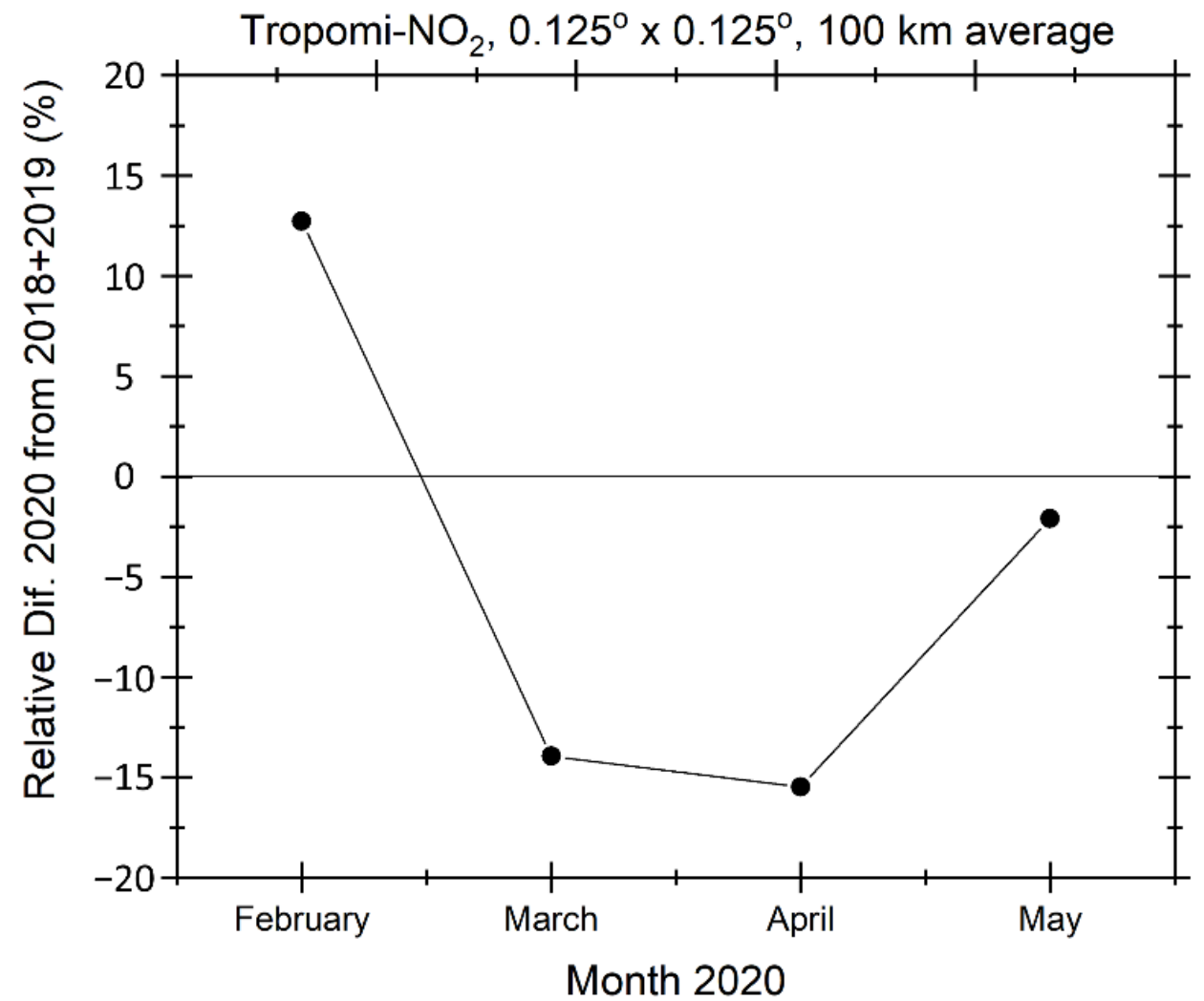

Figure A1. The relative difference (\%) of $\mathrm{NO}_{2}$ columnar concentration for 2020 with respect to the mean 2018-2019 for the months February, March, April and May, as obtained by Tropomi within $50 \mathrm{~km}$ (radius) over Athens, Greece. 

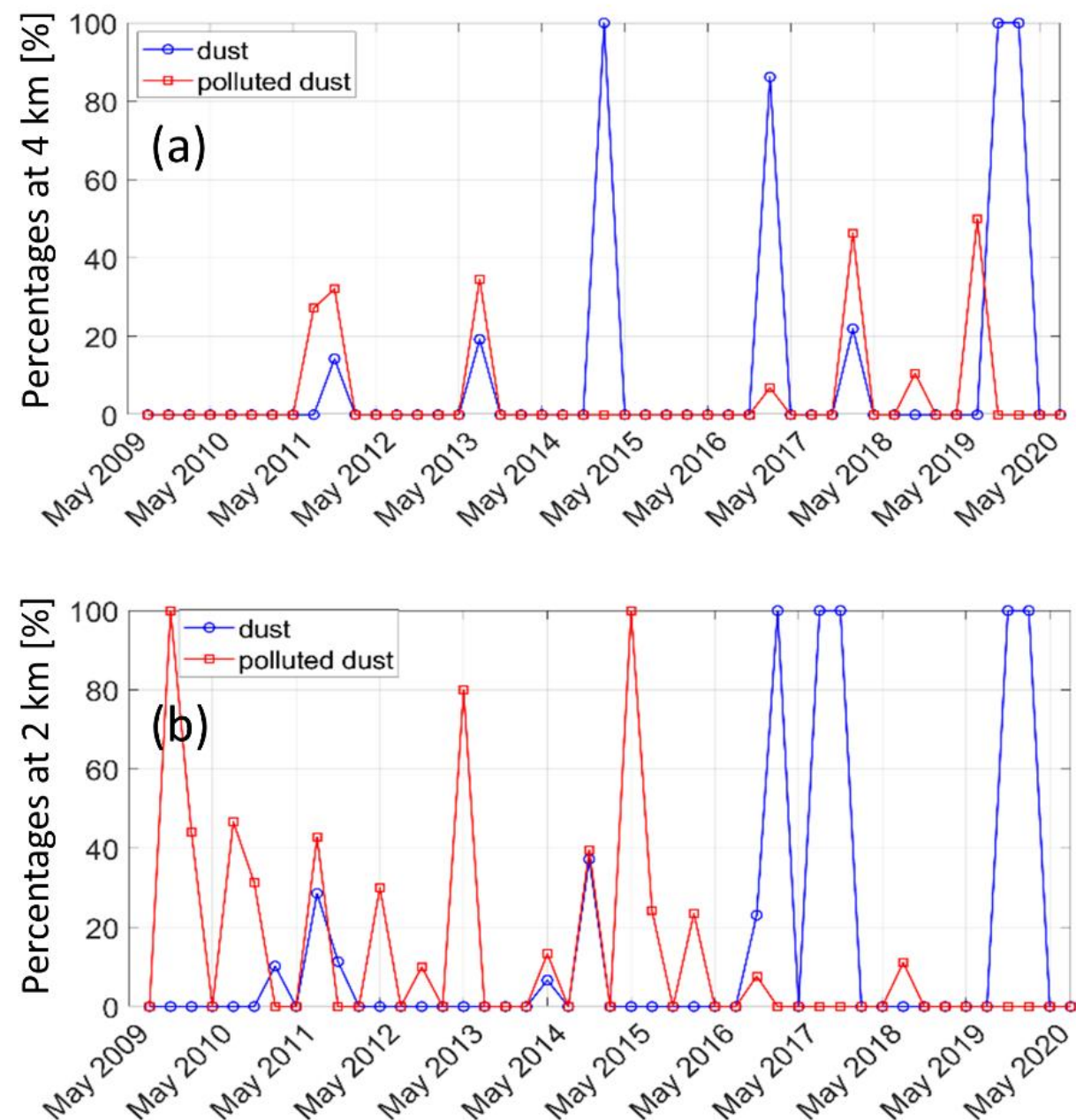

Figure A2. The percentage of pure and polluted dust occurrences for the months of May (2009-2020) as identified by CALIPSO VFM product, within $52.5 \mathrm{~km}$ (radius) over Athens, Greece, for the height levels of (a) 4 and (b) $2 \mathrm{~km}$ asl.

(a)

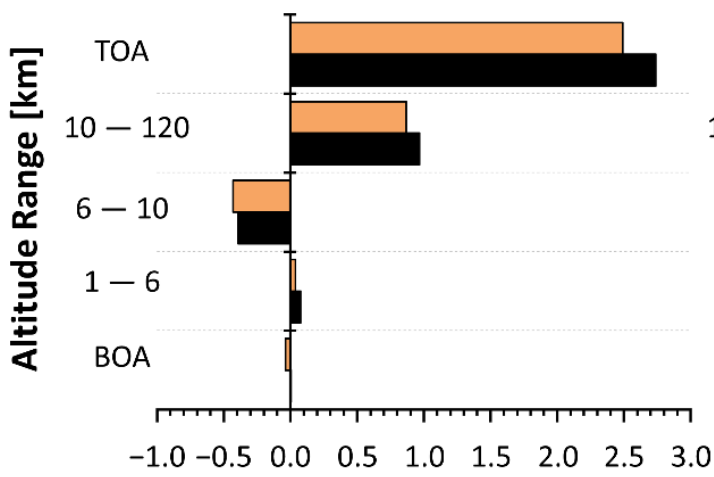

Net heat. rate $(S W+L W)[K / d]$ (b)

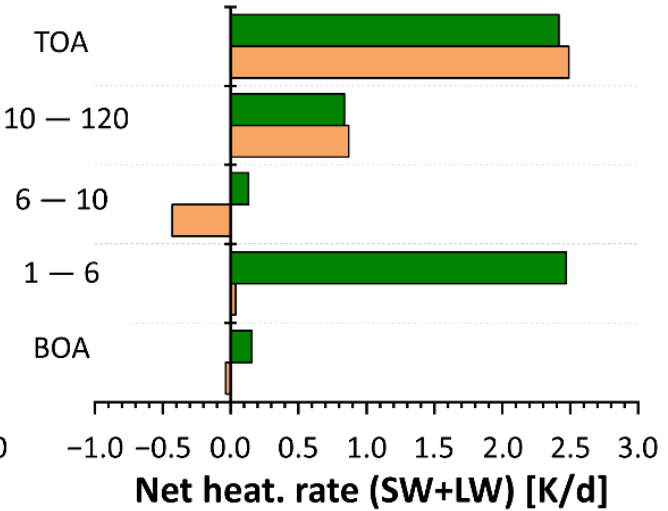

Loaded Atm. Reference Atm.

Figure A3. The net heat rate (a,b) of a typical atmosphere (black bars), a reference atmosphere (orange bars), and a loaded atmosphere (green bars), at 5 atmospheric height ranges. 


\section{References}

1. Harrison, S.P.; Kohfeld, K.E.; Roelandt, C.; Claquin, T. The role of dust in climate changes today, at the last glacial maximum and in the future. Earth-Sci. Rev. 2001, 54, 43-80. [CrossRef]

2. Teller, A.; Levin, Z. The effects of aerosols on precipitation and dimensions of subtropical clouds: A sensitivity study using a numerical cloud model. Atmos. Chem. Phys. 2006, 6, 67-80. [CrossRef]

3. Weinzierl, B.; Sauer, D.; Minikin, A.; Reitebuch, O.; Dahlkötter, F.; Mayer, B.; Emde, C.; Tegen, I.; Gasteiger, J.; Petzold, A.; et al. On the visibility of airborne volcanic ash and mineral dust from the pilot's perspective in flight. Phys. Chem. Earth 2012, 45-46, 87-102. [CrossRef]

4. Griffin, D.W. Atmospheric movement of microorganisms in clouds of desert dust and implications for human health. Clin. Microbiol. Rev. 2007, 20, 459-477. [CrossRef] [PubMed]

5. Baddock, M.C.; Strong, C.L.; Murray, P.S.; McTainsh, G.H. Aeolian dust as a transport hazard. Atmos. Environ. 2013, 71, 7-14. [CrossRef]

6. Middleton, N.; Yiallouros, P.; Kleanthous, S.; Kolokotroni, O.; Schwartz, J.; Dockery, D.W.; Demokritou, P.; Koutrakis, P. A 10-year time-series analysis of respiratory and cardiovascular morbidity in Nicosia, Cyprus: The effect of short-term changes in air pollution and dust storms. Environ. Health A Glob. Access Sci. Source 2008, 7, 1-16. [CrossRef]

7. Goudie, A.S. Desert dust and human health disorders. Environ. Int. 2014, 63, 101-113. [CrossRef]

8. Giannadaki, D.; Pozzer, A.; Lelieveld, J. Modeled global effects of airborne desert dust on air quality and premature mortality. Atmos. Chem. Phys. 2014, 14, 957-968. [CrossRef]

9. Zhang, X.; Zhao, L.; Tong, D.Q.; Wu, G.; Dan, M.; Teng, B. A systematic review of global desert dust and associated human health effects. Atmosphere 2016, 7. [CrossRef]

10. Myhre, G.; Shindell, D.; Bréon, F.-M.; Collins, W.; Fuglestvedt, J.; Huang, J.; Koch, D.; Lamarque, J.-F.; Lee, D.; Mendoza, B.; et al. Anthropogenic and natural radiative forcing. In Climate Change 2013: The Physical Science Basis; Working Group I Contribution to the Fifth Assessment Report of the Intergovernmental Panel on Climate Change; Cambridge University Press: Cambridge, UK, 2013; pp. 659-740. [CrossRef]

11. Adebiyi, A.A.; Kok, J.F. Climate models miss most of the coarse dust in the atmosphere. Sci. Adv. 2020, 6, 1-10. [CrossRef] [PubMed]

12. Andreae, M.O.; Rosenfeld, D. Aerosol-cloud-precipitation interactions. Part 1. The nature and sources of cloud-active aerosols. Earth-Science Rev. 2008, 89, 13-41. [CrossRef]

13. Quijano, A.L.; Sokolik, I.N.; Toon, O.B. Radiative heating rates and direct radiative forcing by mineral dust in cloudy atmospheric conditions. J. Geophys. Res. Atmos. 2000, 105, 12207-12219. [CrossRef]

14. Rosenfeld, D. Suppression of rain and snow by urban and industrial air pollution. Science 2000, 287, 1793-1796. [CrossRef] [PubMed]

15. Sassen, K.; DeMott, P.J.; Prospero, J.M.; Poellot, M.R. Saharan dust storms and indirect aerosol effects on clouds: CRYSTAL-FACE results. Geophys. Res. Lett. 2003, 30,1-4. [CrossRef]

16. Seigel, R.B.; Van Den Heever, S.C.; Saleeby, S.M. Mineral dust indirect effects and cloud radiative feedbacks of a simulated idealized nocturnal squall line. Atmos. Chem. Phys. 2013, 13, 4467-4485. [CrossRef]

17. Pozzer, A.; Dominici, F.; Haines, A.; Witt, C.; Münzel, T.; Lelieveld, J. Regional and global contributions of air pollution to risk of death from COVID-19. Cardiovasc. Res. 2020, 116, 2247-2253. [CrossRef] [PubMed]

18. Mamouri, R.E.; Papayannis, A.; Amiridis, V.; Müller, D.; Kokkalis, P.; Rapsomanikis, S.; Karageorgos, E.T.; Tsaknakis, G.; Nenes, A.; Kazadzis, S.; et al. Multi-wavelength Raman lidar, sun photometric and aircraft measurements in combination with inversion models for the estimation of the aerosol optical and physico-chemical properties over Athens, Greece. Atmos. Meas. Tech. 2012, 5, 1793-1808. [CrossRef]

19. Granados-Muñoz, M.J.; Bravo-Aranda, J.A.; Baumgardner, D.; Guerrero-Rascado, J.L.; Pérez-Ramírez, D.; Navas-Guzmán, F.; Veselovskii, I.; Lyamani, H.; Valenzuela, A.; Olmo, F.J.; et al. A comparative study of aerosol microphysical properties retrieved from ground-based remote sensing and aircraft in situ measurements during a Saharan dust event. Atmos. Meas. Tech. 2016, 9 , 1113-1133. [CrossRef]

20. Soupiona, O.; Papayannis, A.; Kokkalis, P.; Foskinis, R.; Sánchez Hernández, G.; Ortiz-Amezcua, P.; Mylonaki, M.; Papanikolaou, C.-A.; Papagiannopoulos, N.; Samaras, S.; et al. Saharan dust intrusions over the northern Mediterranean region in the frame of EARLINET (2014-2017): Properties and impact in radiative forcing. Atmos. Chem. Phys. 2020, 20, 15147-15166. [CrossRef]

21. Engelstaedter, S.; Tegen, I.; Washington, R. North African dust emissions and transport. Earth-Sci. Rev. 2006, 79, 73-100. [CrossRef]

22. Tanaka, T.Y.; Chiba, M. A numerical study of the contributions of dust source regions to the global dust budget. Glob. Planet. Change 2006, 52, 88-104. [CrossRef]

23. Prospero, J.M. Saharan Dust Transport over the North Atlantic Ocean and Mediterranean: An Overview. Impact Desert Dust Mediterr. 1996, 133-151. [CrossRef]

24. Hamonou, E.; Chazette, P.; Balis, D.; Dulac, F.; Schneider, X.; Galani, E.; Ancellet, G.; Papayannis, A. Characterization of the vertical structure of Saharan dust export to the Mediterranean basin. J. Geophys. Res. Atmos. 1999, 104, 22257-22270. [CrossRef]

25. Dunion, J.P.; Velden, C.S. The impact of the Saharan Air Layer on Atlantic tropical cyclone activity. Bull. Am. Meteorol. Soc. 2004, 85, 353-365. [CrossRef] 
26. Balis, D.; Amiridis, V.; Kazadzis, S.; Papayannis, A.; Tsaknakis, G.; Tzortzakis, S.; Kalivitis, N.; Vrekoussis, M.; Kanakidou, M.; Mihalopoulos, N.; et al. Optical characteristics of desert dust over the east Mediterranean during summer: A case study. Ann. Geophys. 2006, 24, 807-821. [CrossRef]

27. Schepanski, K.; Tegen, I.; Todd, M.C.; Heinold, B.; Bönisch, G.; Laurent, B.; Macke, A. Meteorological processes forcing Saharan dust emission inferred from MSG-SEVIRI observations of subdaily dust source activation and numerical models. J. Geophys. Res. Atmos. 2009, 114, 1-18. [CrossRef]

28. Gkikas, A.; Houssos, E.E.; Lolis, C.J.; Bartzokas, A.; Mihalopoulos, N.; Hatzianastassiou, N. Atmospheric circulation evolution related to desert-dust episodes over the Mediterranean. Q. J. R. Meteorol. Soc. 2015, 141, 1634-1645. [CrossRef]

29. Flaounas, E.; Kotroni, V.; Lagouvardos, K.; Kazadzis, S.; Gkikas, A.; Hatzianastassiou, N. Cyclone contribution to dust transport over the Mediterranean region. Atmos. Sci. Lett. 2015, 16, 473-478. [CrossRef]

30. Ansmann, A.; Bösenberg, J.; Chiakovsky, A.; Comerón, A.; Eckhardt, S.; Eixmann, R.; Freudenthaler, V.; Ginoux, P.; Komguem, L.; Linné, H.; et al. Long-range transport of Saharan dust to northern Europe: The 11-16 October 2001 outbreak observed with EARLINET. J. Geophys. Res. D Atmos. 2003, 108, 1-15. [CrossRef]

31. Meloni, D.; di Sarra, A.; Biavati, G.; DeLuisi, J.J.; Monteleone, F.; Pace, G.; Piacentino, S.; Sferlazzo, D.M. Seasonal behavior of Saharan dust events at the Mediterranean island of Lampedusa in the period 1999-2005. Atmos. Environ. 2007, 41, 3041-3056. [CrossRef]

32. Papayannis, A.; Mamouri, R.-E.; Amiridis, V.; Kazadzis, S.; Pérez García-Pando, C.; Tsaknakis, G.; Kokkalis, P.; Baldasano, J. Systematic lidar observations of Saharan dust layers over Athens, Greece in the frame of EARLINET project (2004-2006). Ann. Geophys. 2009, 27, 3611-3620. [CrossRef]

33. Soupiona, O.; Papayannis, A.; Kokkalis, P.; Mylonaki, M.; Tsaknakis, G.; Argyrouli, A.; Vratolis, S. Long-term systematic profiling of dust aerosol optical properties using the EOLE NTUA lidar system over Athens, Greece (2000-2016). Atmos. Environ. 2018, 183, 165-174. [CrossRef]

34. Soupiona, O.; Samaras, S.; Ortiz-Amezcua, P.; Böckmann, C.; Papayannis, A.; Moreira, G.A.; Benavent-Oltra, J.A.; GuerreroRascado, J.L.; Bedoya-Velásquez, A.E.; Olmo, F.J.; et al. Retrieval of optical and microphysical properties of transported Saharan dust over Athens and Granada based on multi-wavelength Raman lidar measurements: Study of the mixing processes. Atmos. Environ. 2019, 214. [CrossRef]

35. Calidonna, C.R.; Avolio, E.; Gullì, D.; Ammoscato, I.; De Pino, M.; Donateo, A.; Feudo, T. Lo Five years of dust episodes at the Southern Italy GAW regional coastal mediterranean observatory: Multisensors and modeling analysis. Atmosphere 2020, 11. [CrossRef]

36. Veselovskii, I.; Hu, Q.; Goloub, P.; Podvin, T.; Korenskiy, M.; Derimian, Y.; Legrand, M.; Castellanos, P. Variability in lidar-derived particle properties over West Africa due to changes in absorption: Towards an understanding. Atmos. Chem. Phys. 2020, 20, 6563-6581. [CrossRef]

37. Ansmann, A.; Seifert, P.; Tesche, M.; Wandinger, U. Profiling of fine and coarse particle mass: Case studies of Saharan dust and Eyjafjallajökull/Grimsvötn volcanic plumes. Atmos. Chem. Phys. 2012, 12, 9399-9415. [CrossRef]

38. Mona, L.; Liu, Z.; Müller, D.; Omar, A.; Papayannis, A.; Pappalardo, G.; Sugimoto, N.; Vaughan, M. Lidar measurements for desert dust characterization: An overview. Adv. Meteorol. 2012, 2012. [CrossRef]

39. Nisantzi, A.; Mamouri, R.E.; Ansmann, A.; Schuster, G.L.; Hadjimitsis, D.G. Middle East versus Saharan dust extinction-tobackscatter ratios. Atmos. Chem. Phys. 2015, 15, 7071-7084. [CrossRef]

40. Gkikas, A.; Basart, S.; Hatzianastassiou, N.; Marinou, E.; Amiridis, V.; Kazadzis, S.; Pey, J.; Querol, X.; Jorba, O.; Gasso, S.; et al. Mediterranean Intense Desert Dust Outbreaks and Their Vertical Structure Based on Remote Sensing Data. Atmos. Chem. Phys. 2016. [CrossRef]

41. Mamouri, R.E.; Ansmann, A.; Nisantzi, A.; Solomos, S.; Kallos, G.; Hadjimitsis, D.G. Extreme dust storm over the eastern Mediterranean in September 2015: Satellite, lidar, and surface observations in the Cyprus region. Atmos. Chem. Phys. 2016, 16, 13711-13724. [CrossRef]

42. Solomos, S.; Ansmann, A.; Mamouri, R.E.; Binietoglou, I.; Patlakas, P.; Marinou, E.; Amiridis, V. Remote sensing and modelling analysis of the extreme dust storm hitting the Middle East and eastern Mediterranean in September 2015. Atmos. Chem. Phys. 2017, 17, 4063-4079. [CrossRef]

43. Granados-Muñoz, M.J.; Sicard, M.; Papagiannopoulos, N.; Barragán, R.; Bravo-Aranda, J.A.; Nicolae, D. Two-dimensional mineral dust radiative effect calculations from CALIPSO observations over Europe. Atmos. Chem. Phys. 2019, 19, 13157-13173. [CrossRef]

44. Papayannis, A.; Mamouri, R.E.; Amiridis, V.; Remoundaki, E.; Tsaknakis, G.; Kokkalis, P.; Veselovskii, I.; Kolgotin, A.; Nenes, A.; Fountoukis, C. Optical-microphysical properties of Saharan dust aerosols and composition relationship using a multi-wavelength Raman lidar, in situ sensors and modelling: A case study analysis. Atmos. Chem. Phys. 2012, 12, 4011-4032. [CrossRef]

45. Bauwens, M.; Compernolle, S.; Stavrakou, T.; Müller, J.F.; van Gent, J.; Eskes, H.; Levelt, P.F.; van der A, R.; Veefkind, J.P.; Vlietinck, J.; et al. Impact of Coronavirus Outbreak on $\mathrm{NO}_{2}$ Pollution Assessed Using TROPOMI and OMI Observations. Geophys. Res. Lett. 2020, 47, 1-9. [CrossRef]

46. Menut, L.; Bessagnet, B.; Siour, G.; Mailler, S.; Pennel, R.; Cholakian, A. Impact of lockdown measures to combat Covid-19 on air quality over western Europe. Sci. Total Environ. 2020, 741, 140426. [CrossRef]

47. Collivignarelli, M.C.; Abbà, A.; Bertanza, G.; Pedrazzani, R.; Ricciardi, P.; Carnevale Miino, M. Lockdown for CoViD-2019 in Milan: What are the effects on air quality? Sci. Total Environ. 2020, 732, 139280. [CrossRef] 
48. Gautam, S. COVID-19: Air pollution remains low as people stay at home. Air Qual. Atmos. Health 2020, 13, 853-857. [CrossRef]

49. Velavan, T.P.; Meyer, C.G. The COVID-19 epidemic. Trop. Med. Int. Health 2020, 25, 278-280. [CrossRef]

50. Liu, S.; Yang, L.; Zhang, C.; Xiang, Y.T.; Liu, Z.; Hu, S.; Zhang, B. Online mental health services in China during the COVID-19 outbreak. Lancet Psychiatry 2020, 7, e17-e18. [CrossRef]

51. Puca, E.; Čivljak, R.; Arapović, J.; Popescu, C.; Christova, I.; Raka, L.; Cana, F.; Miranović, V.; Karageorgopoulos, D.; Baš, D.; et al. Short epidemiological overview of the current situation on COVID-19 pandemic in Southeast European (SEE) countries. J. Infect. Dev. Ctries. 2020, 14, 433-437. [CrossRef]

52. Grivas, G.; Athanasopoulou, E.; Kakouri, A.; Bailey, J.; Liakakou, E.; Stavroulas, I.; Kalkavouras, P.; Bougiatioti, A.; Kaskaoutis, D.G.; Ramonet, M.; et al. Integrating in situ measurements and city scale modelling to assess the covid-19 lockdown effects on emissions and air quality in athens, greece. Atmosphere 2020, 11, 1174. [CrossRef]

53. Baldasano, J.M. COVID-19 lockdown effects on air quality by $\mathrm{NO}_{2}$ in the cities of Barcelona and Madrid (Spain). Sci. Total Environ. 2020, 741. [CrossRef]

54. Vultaggio, M.; Varrica, D.; Alaimo, M.G. Impact on air quality of the covid-19 lockdown in the urban area of palermo (Italy). Int. J. Environ. Res. Public Health 2020, 17, 7375. [CrossRef] [PubMed]

55. Donzelli, G.; Cioni, L.; Cancellieri, M.; Morales, A.L.; Suárez-Varela, M.M.M. The effect of the covid-19 lockdown on air quality in three italian medium-sized cities. Atmosphere 2020, 11, 1118. [CrossRef]

56. Zerefos, C.S.; Solomos, S.; Kapsomenakis, J.; Poupkou, A.; Dimitriadou, L.; Polychroni, I.D.; Kalabokas, P.; Philandras, C.M.; Thanos, D. Lessons learned and questions raised during and post-COVID-19 anthropopause period in relation to the environment and climate. Environ. Dev. Sustain. 2020. [CrossRef] [PubMed]

57. Lolli, S.; Chen, Y.C.; Wang, S.H.; Vivone, G. Impact of meteorological conditions and air pollution on COVID-19 pandemic transmission in Italy. Sci. Rep. 2020, 10, 1-15. [CrossRef]

58. Selvam, S.; Muthukumar, P.; Venkatramanan, S.; Roy, P.D.; Manikanda Bharath, K.; Jesuraja, K. SARS-CoV-2 pandemic lockdown: Effects on air quality in the industrialized Gujarat state of India. Sci. Total Environ. 2020, 737, 140391. [CrossRef]

59. Adams, M.D. Air pollution in Ontario, Canada during the COVID-19 State of Emergency. Sci. Total Environ. 2020, $742,140516$. [CrossRef]

60. Krecl, P.; Targino, A.C.; Oukawa, G.Y.; Cassino Junior, R.P. Drop in urban air pollution from COVID-19 pandemic: Policy implications for the megacity of São Paulo. Environ. Pollut. 2020, 265, 114883. [CrossRef] [PubMed]

61. Mostafa, M.K.; Gamal, G.; Wafiq, A. The impact of COVID 19 on air pollution levels and other environmental indicators-A case study of Egypt. J. Environ. Manag. 2021, 277, 111496. [CrossRef] [PubMed]

62. Kanniah, K.D.; Kamarul Zaman, N.A.F.; Kaskaoutis, D.G.; Latif, M.T. COVID-19's impact on the atmospheric environment in the Southeast Asia region. Sci. Total Environ. 2020, 736, 139658. [CrossRef]

63. Papayannis, A.; Kokkalis, P.; Mylonaki, M.; Soupiona, R.; Papanikolaou, C.A.; Foskinis, R. Recent upgrades of the EOLE and AIAS lidar systems of the National Technical University of Athens operating since 2000 in Athens, Greece. EPJ Web Conf. 2020, 2030, 4-7. [CrossRef]

64. Freudenthaler, V. About the effects of polarising optics on lidar signals and the $\Delta 90$ calibration. Atmos. Meas. Tech. 2016, 9 , 4181-4255. [CrossRef]

65. D'Amico, G.; Amodeo, A.; Baars, H.; Binietoglou, I.; Freudenthaler, V.; Mattis, I.; Wandinger, U.; Pappalardo, G. EARLINET Single Calculus Chain-overview on methodology and strategy. Atmos. Meas. Tech. 2015, 8, 4891-4916. [CrossRef]

66. Mattis, I.; D'Amico, G.; Baars, H.; Amodeo, A.; Madonna, F.; Iarlori, M. EARLINET Single Calculus Chain-Technical—Part 2: Calculation of optical products. Atmos. Meas. Tech. 2016, 9, 3009-3029. [CrossRef]

67. Ansmann, A.; Riebesell, M.; Wandinger, U.; Weitkamp, C.; Voss, E.; Lahmann, W.; Michaelis, W. Combined raman elasticbackscatter LIDAR for vertical profiling of moisture, aerosol extinction, backscatter, and LIDAR ratio. Appl. Phys. B Photophys. Laser Chem. 1992, 55, 18-28. [CrossRef]

68. Mattis, I.; Ansmann, A.; Müller, D.; Wandinger, U.; Althausen, D. Dual-wavelength Raman lidar observations of the extinction-tobackscatter ratio of Saharan dust. Geophys. Res. Lett. 2002, 29, 20-1-20-4. [CrossRef]

69. Kokkalis, P. Using paraxial approximation to describe the optical setup of a typical EARLINET lidar system. Atmos. Meas. Tech. 2017, 10, 3103-3115. [CrossRef]

70. Amodeo, A.; D’Amico, G.; Giunta, A.; Papagiannopoulos, N.; Papayannis, A.; Argyrouli, A.; Mylonaki, M.; Tsaknakis, G.; Kokkalis, P.; Soupiona, O.; et al. ATHLI16: The ATHens Lidar Intercomparison campaign. EPJ Web Conf. 2018, 176, 9008. [CrossRef]

71. Vratolis, S.; Fetfatzis, P.; Argyrouli, A.; Papayannis, A.; Müller, D.; Veselovskii, I.; Bougiatioti, A.; Nenes, A.; Remoundaki, E.; Diapouli, E.; et al. A new method to retrieve the real part of the equivalent refractive index of atmospheric aerosols. J. Aerosol Sci. 2018, 117, 54-62. [CrossRef]

72. Querol, X.; Pérez, N.; Reche, C.; Ealo, M.; Ripoll, A.; Tur, J.; Pandolfi, M.; Pey, J.; Salvador, P.; Moreno, T.; et al. African dust and air quality over Spain: Is it only dust that matters? Sci. Total Environ. 2019, 686, 737-752. [CrossRef] [PubMed]

73. Grell, G.A.; Peckham, S.E.; Schmitz, R.; McKeen, S.A.; Frost, G.; Skamarock, W.C.; Eder, B. Fully coupled "online" chemistry within the WRF model. Atmos. Environ. 2005, 39, 6957-6975. [CrossRef] 
74. Powers, J.G.; Klemp, J.B.; Skamarock, W.C.; Davis, C.A.; Dudhia, J.; Gill, D.O.; Coen, J.L.; Gochis, D.J.; Ahmadov, R.; Peckham, S.E.; et al. The weather research and forecasting model: Overview, system efforts, and future directions. Bull. Am. Meteorol. Soc. 2017, 98, 1717-1737. [CrossRef]

75. Janić, Z.I. Nonsingular Implementation of the Mellor-Yamada Level 2.5 Scheme in the NCEP Meso Model. 2001. Available online: https:/ / repository.library.noaa.gov/view/noaa/11409 (accessed on 22 December 2020).

76. Chen, F.; Dudhia, J. Coupling an Advanced Land Surface-Hydrology Model with the Penn State-NCAR MM5 Modeling System. Part I: Model Implementation and Sensitivity. Mon. Weather Rev. 2001, 129, 569-585. [CrossRef]

77. Jones, S.L.; Adams-Selin, R.; Hunt, E.D.; Creighton, G.A.; Cetola, J.D. Update on modifications to WRF-CHEM GOCART for fine-scale dust forecasting at AFWA. In AGU Fall Meeting Abstracts; American Geophysical Union: Washington, DC, USA, 2012.

78. Bréon, F.M.; Vermeulen, A.; Descloitres, J. An evaluation of satellite aerosol products against sunphotometer measurements. Remote Sens. Environ. 2011, 115, 3102-3111. [CrossRef]

79. Nabat, P.; Somot, S.; Mallet, M.; Chiapello, I.; Morcrette, J.J.; Solmon, F.; Szopa, S.; Dulac, F.; Collins, W.; Ghan, S.; et al. A 4-D climatology (1979-2009) of the monthly tropospheric aerosol optical depth distribution over the Mediterranean region from a comparative evaluation and blending of remote sensing and model products. Atmos. Meas. Tech. 2013, 6, 1287-1314. [CrossRef]

80. Levy, R.C.; Remer, L.A.; Kleidman, R.G.; Mattoo, S.; Ichoku, C.; Kahn, R.; Eck, T.F. Global evaluation of the Collection 5 MODIS dark-target aerosol products over land. Atmos. Chem. Phys. 2010, 10, 10399-10420. [CrossRef]

81. Tanré, D.; Kaufman, Y.J.; Herman, M.; Mattoo, S. Remote sensing of aerosol properties over oceans using the MODIS/EOS spectral radiances. J. Geophys. Res. Atmos. 1997, 102, 16971-16988. [CrossRef]

82. Kaufman, Y.J.; Koren, I.; Remer, L.A.; Tanré, D.; Ginoux, P.; Fan, S. Dust transport and deposition observed from the TerraModerate Resolution Imaging Spectroradiometer (MODIS) spacecraft over the Atlantic Ocean. J. Geophys. Res. D Atmos. 2005, 110, 1-16. [CrossRef]

83. Pérez, C.; Haustein, K.; Janjic, Z.; Jorba, O.; Huneeus, N.; Baldasano, J.M.; Black, T.; Basart, S.; Nickovic, S.; Miller, R.L.; et al. Atmospheric dust modeling from meso to global scales with the online NMMB/BSC-Dust model \&ndash; Part 1: Model description, annual simulations and evaluation. Atmos. Chem. Phys. 2011, 11, 13001-13027. [CrossRef]

84. Haustein, K.; Pérez, C.; Baldasano, J.M.; Jorba, O.; Basart, S.; Miller, R.L.; Janjic, Z.; Black, T.; Nickovic, S.; Todd, M.C.; et al Atmospheric dust modeling from meso to global scales with the online NMMB/BSC-Dust model—Part 2: Experimental campaigns in Northern Africa. Atmos. Chem. Phys. 2012, 12, 2933-2958. [CrossRef]

85. Stein, A.F.; Draxler, R.R.; Rolph, G.D.; Stunder, B.J.B.; Cohen, M.D.; Ngan, F. Noaa's hysplit atmospheric transport and dispersion modeling system. Bull. Am. Meteorol. Soc. 2015, 96, 2059-2077. [CrossRef]

86. Solomos, S.; Bougiatioti, A.; Soupiona, O.; Papayannis, A.; Mylonaki, M.; Papanikolaou, C.; Argyrouli, A.; Nenes, A. Effects of regional and local atmospheric dynamics on the aerosol and CCN load over Athens. Atmos. Environ. 2019, 197, 53-65. [CrossRef]

87. Solomos, S.; Kalivitis, N.; Mihalopoulos, N.; Amiridis, V.; Kouvarakis, G.; Gkikas, A.; Binietoglou, I.; Tsekeri, A.; Kazadzis, S.; Kottas, M.; et al. From tropospheric folding to Khamsin and Foehn winds: How atmospheric dynamics advanced a recordbreaking dust episode in Crete. Atmosphere 2018, 9, 240. [CrossRef]

88. Kokkalis, P.; Alexiou, D.; Papayannis, A.; Rocadenbosch, F.; Soupiona, O.; Raptis, P.I.; Mylonaki, M.; Tzanis, C.G.; Christodoulakis, J. Application and Testing of the Extended-Kalman-Filtering Technique for Determining the Planetary Boundary-Layer Height over Athens, Greece. Boundary-Layer Meteorol. 2020, 176, 125-147. [CrossRef]

89. Lucia, M.; Amodeo, A.; Pandolfi, M.; Pappalardo, G. Saharan dust intrusions in the Mediterranean area: Three years of Raman lidar measurements. J. Geophys. Res. 2006, 111. [CrossRef]

90. Groß, S.; Freudenthaler, V.; Schepanski, K.; Toledano, C.; Schäfler, A.; Ansmann, A.; Weinzierl, B. Optical properties of long-range transported Saharan dust over Barbados as measured by dual-wavelength depolarization Raman lidar measurements. Atmos. Chem. Phys. 2015, 15, 11067-11080. [CrossRef]

91. Veselovskii, I.; Goloub, P.; Podvin, T.; Bovchaliuk, V.; Derimian, Y.; Augustin, P.; Fourmentin, M.; Tanre, D.; Korenskiy, M.; Whiteman, D.N.; et al. Retrieval of optical and physical properties of African dust from multiwavelength Raman lidar measurements during the SHADOW campaign in Senegal. Atmos. Chem. Phys. 2016, 16, 7013-7028. [CrossRef]

92. Müller, D.; Ansmann, A.; Mattis, I.; Tesche, M.; Wandinger, U.; Althausen, D.; Pisani, G. Aerosol-type-dependent lidar ratios observed with Raman lidar. J. Geophys. Res. Atmos. 2007, 112. [CrossRef]

93. Freudenthaler, V.; Esselborn, M.; Wiegner, M.; Heese, B.; Tesche, M.; Ansmann, A.; Müller, D.; Althausen, D.; Wirth, M.; Fix, A.; et al. Depolarization ratio profiling at several wavelengths in pure Saharan dust during SAMUM 2006. Tellus Ser. B Chem. Phys. Meteorol. 2009, 61, 165-179. [CrossRef]

94. Groß, S.; Esselborn, M.; Weinzierl, B.; Wirth, M.; Fix, A.; Petzold, A. Aerosol classification by airborne high spectral resolution lidar observations. Atmos. Chem. Phys. 2013, 13, 2487-2505. [CrossRef]

95. Ansmann, A.; Petzold, A.; Kandler, K.; Tegen, I.; Wendisch, M.; Müller, D.; Weinzierl, B.; Müller, T.; Heintzenberg, J. Saharan Mineral Dust Experiments SAMUM-1 and SAMUM-2: What have we learned? Tellus Ser. B Chem. Phys. Meteorol. 2011, 63, 403-429. [CrossRef]

96. Tesche, M.; Ansmann, A.; Müller, D.; Althausen, D.; Engelmann, R.; Freudenthaler, V.; Groß, S. Vertically resolved separation of dust and smoke over Cape Verde using multiwavelength Raman and polarization lidars during Saharan Mineral Dust Experiment 2008. J. Geophys. Res. Atmos. 2009, 114, 1-14. [CrossRef] 
97. Groß, S.; Tesche, M.; Freudenthaler, V.; Toledano, C.; Wiegner, M.; Ansmann, A.; Althausen, D.; Seefeldner, M. Characterization of Saharan dust, marine aerosols and mixtures of biomass-burning aerosols and dust by means of multi-wavelength depolarization and Raman lidar measurements during SAMUM 2. Tellus Ser. B Chem. Phys. Meteorol. 2011, 63, 706-724. [CrossRef]

98. Groß, S.; Gasteiger, J.; Freudenthaler, V.; Müller, T.; Sauer, D.; Toledano, C.; Ansmann, A. Saharan dust contribution to the Caribbean summertime boundary layer-A lidar study during SALTRACE. Atmos. Chem. Phys. 2016, 16, 11535-11546. [CrossRef]

99. Emde, C.; Buras-Schnell, R.; Kylling, A.; Mayer, B.; Gasteiger, J.; Hamann, U.; Kylling, J.; Richter, B.; Pause, C.; Dowling, T.; et al. The libRadtran software package for radiative transfer calculations (version 2.0.1). Geosci. Model Dev. 2016, 9, 1647-1672. [CrossRef]

100. Koepke, P.; Gasteiger, J.; Hess, M. Technical Note: Optical properties of desert aerosol with non-spherical mineral particles: Data incorporated to OPAC. Atmos. Chem. Phys. 2015, 15, 5947-5956. [CrossRef]

101. Sicard, M.; Bertolín, S.; Mallet, M.; Dubuisson, P.; Comerón, A. Estimation of mineral dust long-wave radiative forcing: Sensitivity study to particle properties and application to real cases in the region of Barcelona. Atmos. Chem. Phys. 2014, 14, 9213-9231. [CrossRef]

102. Anderson, G.; Clough, S.; Kneizys, F. AFGL Atmospheric Constituent Profiles; Tech. Rep. AFGL-TR-86-0110; Air Force Geophys. Lab.: Hanscom, MA, USA, 1986; p. 46.

103. Raptis, I.-P.; Eleftheratos, K.; Kazadzis, S.; Kosmopoulos, P. The Combined Effect of Ozone and Aerosols on Erythemal Irradiance in an Extremely Low Ozone Event during May 2020. Atmosphere 2021, 12, 145. [CrossRef] 